\title{
Doorwerking van aandeelhoudersovereenkomsten in het vennootschapsrecht
}

\author{
Een analyse in de context van de persoonsgebonden \\ vennootschap
}

Richard Nowak en Tom van Duuren*

\section{Inleiding: institutionele vs. contractuele visie}

Het Nederlandse vennootschapsrecht maakt deel uit van het privaatrecht en in dit preadvies bespreken wij de tendens in rechtspraak en literatuur in de laatste vijftien jaar om aan overeenkomsten tussen aandeelhouders een zekere mate van doorwerking in de vennootschappelijke sfeer toe te kennen. Deze tendens is versterkt door invoering van de Wet vereenvoudiging en flexibilisering bv-recht op I oktober 2012. In het klassieke bv-recht staat de kapitaalinbreng van de aandeelhouder centraal. De aandelen in een bv zijn - net als de aandelen in een nv - overdraagbaar, zij het dat de statuten tot de invoering van het nieuwe bv-recht een blokkeringsregeling moesten bevatten. In deze zin was de bv weliswaar besloten doch ongeschikt voor het herbergen van een persoonsgebonden samenwerking tussen de aandeelhouders. In de klassieke - naar onze mening verouderde - opvatting van de institutionele theorie treden de samenwerkende partners na de oprichting van 'hun' bv naar de achtergrond. Het samenwerkingsverband treedt zelf, in de gedaante van een rechtspersoon, op de voorgrond en wordt geregeerd door regels van eigen aard, waarbij de nadruk wordt gelegd op de dualistische structuur van de bv (een verplicht bestuursorgaan met een eigen rol naast de algemene vergadering). Binnen deze rechtspersoon oefenen de samenwerkende partners in hoedanigheid van aandeelhouders bevoegdheden uit als algemene vergadering. De persoon van de individuele aandeelhouder speelt binnen de bv - nog steeds volgens de klassieke opvatting - geen rol van betekenis buiten zijn deelname in het kapitaal van de rechtspersoon. Hieraan wordt traditiegetrouw de gedachte gekoppeld dat het vermogensrecht naar de

* Mr. R.G.J. Nowak is advocaat te Amsterdam en onderzoeker aan de Radboud Universiteit. Mr. T.P. van Duuren is notaris te Amsterdam. 
achtergrond verdwijnt. Over het algemeen zouden er geen verplichtingen zijn aan te wijzen die de aandeelhouders tegenover elkaar hebben. ${ }^{\mathrm{I}}$

De in deze zin opgevatte institutionele theorie is niet geschikt als normatief uitgangspunt bij de analyse van de rechtsverhoudingen tussen aandeelhouders in een persoonsgebonden bv. Het inwendige bestel van de persoonsgebonden bv wordt immers in de praktijk tot op grote hoogte bepaald door de regelingen in overeenkomsten en statuten, reglementen en andere documenten die de samenwerkende partners in vrijheid met elkaar hebben uitonderhandeld. De aandeelhouders hebben derhalve een actieve en bepalende betrokkenheid bij de totstandkoming van hun samenwerkingsverband ('de onderlinge regeling tot samenwerking'). Het samenwerkingskarakter, de onderlinge afhankelijkheid van de aandeelhouders en de doelgebondenheid van de rechtsbetrekking maken dat persoonsgebonden bv's intuitu personae worden aangegaan. Deze karaktertrek hebben zij gemeen met personenvennootschappen.

Een hoofdregel van privaatrecht is dat het (rechts)personen in beginsel vrijstaat te beslissen met wie zij een bepaalde rechtsverhouding tot stand willen brengen. ${ }^{2}$ De vrijheid van ondernemerschap en commerciële associatie zijn grondrechten. ${ }^{3}$ Samenwerkende ondernemers hebben derhalve binnen Europa goede papieren en de Nederlandse wetgever heeft zich dat bij de invoering van het nieuwe, geflexibiliseerde, bv-recht terdege gerealiseerd. De partijautonomie en inrichtingsvrijheid staan in het nieuwe recht voorop. In de wetsgeschiedenis komt zelfs de ambitie naar voren om de voorheen bestaande noodzaak tot contractuele aanvulling van statutaire afspraken op te heffen althans ingrijpend te reduceren. ${ }^{4}$ Het instrument waarvan de wetgever zich hierbij, onder andere, heeft bediend is het ingrijpend mitigeren van het dwingendrechtelijk karakter van de wettelijke regeling.

Vanuit historisch perspectief is het institutionele karakter van de Nederlands bv allerminst vanzelfsprekend. De bv werd tot 1976 geregeld in het Wetboek van Koophandel, zij aan zij met de nv, de vof en de cv. Dat de wetgever de bv en nv gebroederlijk behandelde met een tweetal gekwalificeerde maatschappen is niet verwonderlijk. De nv werd aanvankelijk door de wetgever en in de rechtspraak geduid als een gekwalificeerde maatschap. In deze contractuele visie op de nv werden de aandeelhouders gezien als partners die als contractspartijen de vennootschap beheersten. De algemene vergadering vormde de hoogste macht en de bestuurders waren 'slechts' lasthebbers van de aandeelhouders. Hieruit vloeide logischerwijze ook de

I Zie verder over de institutionele visie op de vennootschap en het onderscheid met de contractuele visie: Asser/Maeijer/Van Solinge \& Nieuwe Weme 2-II^ 2009, nr. II, Van Schilfgaarde/Winter 2003, nr. I. en C.M. Raaijmakers, Ondernemingsrecht (Pitlo/Raaijmakers deel 2), Deventer: Kluwer 2006, p. I67-I72.

2 Art. II EVRM geeft uitdrukking aan de autonome vrijheid van vereniging zonder dat commerciële overwegingen een rol spelen bij de uitoefening van dit grondrecht. Associatie in het kader van een bv of nv valt derhalve rechtstreeks onder de Europeesrechtelijke verenigingsvrijheid; zie ook A.K. Koekkoek en P.W.C. Akkermans (red.), De Grondwet. Een artikelsgewijs commentaar, Zwolle: W.E.J. Tjeenk Willink I992, p. 204 e.v.

3 Art. II-I6 van het ontwerp voor een Europese Grondwet noemt met zoveel woorden het grondrecht van de vrijheid van ondernemerschap naast het grondrecht van de verenigingsvrijheid.

4 Kamerstukken II 2008/09, 3I 058, nr. 6, p. 20. 
vrijheid voort van de vennoten/aandeelhouders om de structuur en inrichting van hun vennootschap te bepalen. De vennootschapswetgeving van I928 ademde deze vrije geest. In de vijftiger jaren van de vorige eeuw trad echter een kentering op in de contractuele visie. De nv werd meer en meer gezien als een van de aandeelhouder verzelfstandigde vennootschap met een eigen vennootschappelijk belang. De nadruk werd gelegd op de dualistische structuur met een systeem van checks en balances. Machtenscheiding tussen bestuur en aandeelhouders werd gezien als onderdeel van de duurzame structuur van de bv en nv. De aandeelhouders waren in deze benadering eerder anonieme kapitaalverschaffers dan samenwerkende partners.

In de zevende druk van het Handboek uit I962 nam Van der Grinten voor het eerst afstand van de contractuele visie op de nv. Hij behandelde de nv voor het eerst als een rechtsfiguur van eigen aard. Zijn belangrijkste argument was dat de rechtswerkelijkheid hiertoe noopte. ${ }^{5}$ Het was ook de tijd waarin Meijers zijn ontwerp voor het nieuwe BW het licht deed zien. De opname van de rechtspersoon in het Burgerlijk Wetboek is voor Van der Grinten mede een reden geweest om over te stappen op de institutionele leer. ${ }^{6}$ Raaijmakers heeft er voorts op gewezen dat de politieke ontwikkeling rond de vermaatschappelijking van de onderneming in de periode tot de invoering van Boek 2 BW in 1976 een cruciale rol heeft gespeeld bij de verdere institutionalisering van het Nederlandse bv- en nv-recht.? Interessant is dat de verandering van het denken met betrekking tot de nv zich grotendeels heeft afgespeeld op basis van de wettekst van 1928. Er vond in de aanloop naar de invoering van Boek 2 BW als het ware een herijking plaats van de gangbare wetsinterpretatie. Dat is ook de reden waarom de Nederlandse bv- en nv-wetgeving op sommige plaatsen nog steeds de trekken van een personenvennootschap bleef vertonen. Zo definieerden de artikelen 2:64 en I75 lid I BW tot I januari I987 de naamloze en besloten vennootschap als een rechtspersoonlijkheid bezittende vennootschap met een in aandelen verdeeld maatschappelijk kapitaal waarin ieder der vennoten [cursivering door preadviseurs] voor één of meer aandelen deelneemt. Een ander voorbeeld is de tekst van artikel 2:2I6 lid I BW die tot invoering van de Wet vereenvoudiging en flexibilisering bv-recht op I oktober 2012 als volgt luidde: 'Voor zover bij de statuten niet anders is bepaald, komt de winst de aandeelhouders ten goede.' De huidige tekst van artikel 2:105 lid I BW bepaalt tot op de dag van vandaag voor de nv nog steeds hetzelfde. Het effect van deze bepaling is dat indien de statuten zwijgen, de aandeelhouders een rechtstreeks recht op uitkering van de vastgestelde winst hebben. Een voorafgaand besluit tot winstuitkering is daarvoor niet nodig. Ditzelfde principe geldt voor de vennoten van de personenvennootschap.

De omschakeling van de contractuele visie op de institutionele visie werd onderstreept door het Forumbank-arrest (de algemene vergadering is niet de hoogste macht binnen de vennootschap). ${ }^{8}$ De contractuele visie paste niet meer bij de grotere, open nv's met een gespreid aandelenbezit. In dergelijke vennootschappen zijn de

5 E.J.J. van der Heijden en W.C.L. van der Grinten, Handboek voor de Naamloze Vennootschap naar Nederlands recht, 7e druk, Zwolle: W.E.J. Tjeenk Willink I962, p. 4I.

6 Van der Heijden en Van der Grinten I962, Voorwoord, p. 38.

7 Pitlo/Raaijmakers 2006, p. I70.

8 HR 2I januari I955, NJ I959, 43. 
aandeelhouders veeleer beleggers in het kapitaal van de nv. Zeer belangrijk in dit opzicht is geweest de waterscheiding die Meijers aanbracht tussen personen- en kapitaalvennootschappen [cursivering door preadviseurs]:

'Het heeft een punt van overweging uitgemaakt of de naamloze vennootschappen in aansluiting op de overige vennootschappen zouden worden geregeld danwel tezamen met de andere rechtspersonen in één boek zouden worden behandeld. Het laatste is verkozen, omdat de organisatie der naamloze vennootschappen in vele opzichten met die der verenigingen overeenstemt, vooral in ons land, waar de wettelijke regeling der vereniging ook geldt voor verenigingen met commercieel doel. Vennootschappen onder firma daarentegen hebben haar plaats in het contractenrecht behouden(...).Voor deze plaatsing bestaat een goede reden: vennootschappen onder firma worden gedurende haar ganse bestaan door het vennootschapscontract, een overeenkomst, die aan de algemene regels van overeenkomsten onderworpen is beheerst. Bij de naamloze vennootschappen daarentegen bestaan contractuele verhoudingen tussen de oprichters slechts tot de oprichting der NV is voltooid. Deze contractuele verhoudingen hebben juist ten doel tot de oprichting der rechtspersonen, de naamloze vennootschappen, te komen. Daarna bestaan tussen de leden der NV slechts lidmaatschapsverhoudingen.' 9

Toen de bv werd ingevoerd was de institutionele visie inmiddels heersend en deelde de bv, als kloon van de nv, in hetzelfde lot.

Het startschot voor de ingrijpende wetgevingsoperatie die uiteindelijk heeft geleid tot invoering van de Wet vereenvoudiging en flexibilisering bv-recht werd al in 2004 gegeven door het rapport van de Expertgroep vereenvoudiging en flexibilisering bvrecht onder voorzitterschap van prof. mr. H.J. de Kluiver (hierna: de Expertgroep). Bij het denken over de vormgeving van het nieuwe bv-recht heeft de Expertgroep als fundamenteel uitgangspunt genomen dat de bv een toegankelijke rechtsvorm moet zijn voor private ondernemingen. ${ }^{\mathrm{IO}}$ De herwonnen vrijheid in het vennootschapsrecht heeft in het geflexibiliseerde bv-recht ook duidelijke contouren gekregen door invoering van de ruime mogelijkheden om 'verplichtingen van verbintenisrechtelijke aard' van aandeelhouders in de statuten te creëren. Het nieuwe artikel 2:I92 BW geeft een expliciete wettelijk basis aan het opnemen van allerhande verbintenissen in de statuten. Het gaat hier om 'gewone' verbintenissen, dus om vermogensrechtelijke verplichtingen tot het verrichten van bepaalde prestaties. Voor ons onderwerp zijn het meest interessant de verbintenissen van aandeelhouders (I) jegens de vennootschap of tussen aandeelhouders onderling (artikel 2:I92 lid I, onder a, BW) en (2) in verband met de gehoudenheid om aandelen aan te bieden en over te dragen (artikel 2:I92 lid I, onder c, BW). Ten aanzien van deze onderwerpen wordt het schot

9 Toelichting NBW (algemene inleiding), paragraaf 6.

Io Eindrapport Expertgroep van 6 mei 2004 opgenomen in: F.J.P. van den Ingh en R.G.J. Nowak, Vereenvoudiging en flexibilisering bv-recht (deel I). De pre-parlementaire geschiedenis (Serie vanwege het Van der Heijden Instituut, deel 85), Deventer: Kluwer 2006, p. 177-178. 
tussen vennootschapsrecht en vermogensrecht als het ware geslecht. Dit komt de functionaliteit van het vennootschapsrecht zeker ten goede. Het baant de weg om de vermogensrechtelijke aspecten die verband houden met vennootschapsrechtelijke verhoudingen te benaderen vanuit de vermogensrechtelijke systematiek. ${ }^{\text {II }}$ Wij werken dit aspect nader uit in paragraaf 3 .

Een belangrijk uitgangspunt van het nieuwe recht blijft de (thans wettelijk voorgeschreven) regel dat bestuurders zich bij hun handelen moeten richten naar het belang van de vennootschap en de met haar verbonden onderneming. ${ }^{12}$ In de memorie van toelichting spreekt de wetgever in dit verband over de noodzaak om een evenwicht te vinden tussen enerzijds de vrijheid van aandeelhouders om hun samenwerkingsrelatie naar eigen wens vorm te geven en anderzijds de belangen van andere partijen. ${ }^{13}$ Desondanks wordt erkend dat de grotere flexibiliteit die de wet aan oprichters en aandeelhouders biedt de invulling van het vennootschappelijke belang in persoonsgebonden verhoudingen kan inkleuren. Wij citeren uit de memorie van toelichting:

'Bij kleine vennootschappen met een beperkt aantal aandeelhouders zal het vennootschappelijke belang dichter liggen bij het belang van de aandeelhouders dan bij een grote vennootschap met veel werknemers en maatschappelijke belangen. In een wettelijke regeling die meer differentiatie tussen bv's mogelijk zal maken, kan aldus iedere bv op de eigen merites worden beoordeeld.' ${ }^{14}$

Gesteld kan dus worden dat de inhoud van het begrip vennootschappelijk belang niet in steen is gebeiteld. In een persoonsgebonden bv staat het belang van de samenwerkende aandeelhouders centraal. Een raad van commissarissen ontbreekt doorgaans en een groot aantal soorten bestuursbesluiten moet door de algemene vergadering worden goedgekeurd. Indien de belangen van andere stakeholders niet in het geding zijn, loopt het aandeelhoudersbelang parallel aan het vennootschappelijke belang ${ }^{15}$ waardoor het institutionele karakter van een persoonsgebonden bv geen leitmotiv is. Raaijmakers spreekt van een quasi vof-bv. ${ }^{16}$

In dit preadvies staat de vraag centraal in hoeverre het aandeelhouders van een persoonsgebonden bv is toegestaan om afspraken te maken over (de uitoefening van) hun vennootschapsrechtelijke bevoegdheden. Wij gaan daarbij uit van de situatie dat alle aandeelhouders zich ook contractueel hebben verbonden. Anders gezegd, welke ruimte biedt de wettelijke regeling voor het doorwerken van contractuele regelingen in het vennootschapsrecht? In dit kader is het leerzaam om kennis te

II Zie voor eenzelfde benadering W.J.M. van Veen, Zwevend Recht, Rede uitgesproken bij de aanvaarding van het ambt van hoogleraar Vennootschaps- en Rechtspersonenrecht aan de Rechtenfaculteit van de Vrije Universiteit Amsterdam op 3 december 2008.

I2 Art. 2:239 lid 5 BW.

I3 Kamerstukken II 2006/07, 3I 058, nr. 3, p. 3 (MvT).

I4 Kamerstukken II 2006/07, 3I 058, nr. 3, p. 3 (MvT).

I5 T.P. van Duuren, De joint venture-vennootschap. Een persoonsgebonden kapitaalvennootschap (diss. Tilburg) (Uitgave vanwege het Center for Company Law, Schoordijk Instituut), Den Haag: Boom Juridische uitgevers 2002, p. 49 en p. 68.

Pitlo/Raaijmakers 2006, p. 237-24I. 
nemen van een recente rechtsontwikkeling in een ander deel van het Koninkrijk. Wij doelen op de rechtsfiguur van de 'vennootschappelijke overeenkomst' die op I januari 2012 zijn intrede heeft gedaan in het Curaçaose nv- en bv-recht. ${ }^{17}$ Deze vennootschappelijke overeenkomst wordt wettelijk gedefinieerd als een aandeelhoudersovereenkomst die aan de volgende, cumulatieve, eisen voldoet:

- de overeenkomst wordt schriftelijk vastgelegd en aangeduid als 'vennootschappelijke overeenkomst';

- de statuten bepalen dat de nv respectievelijk bv kan toetreden tot een vennootschappelijke overeenkomst;

- alle aandeelhouders en de vennootschap zelf zijn partij bij de vennootschappelijke overeenkomst;

- de statuten bepalen uitdrukkelijk dat geen aandelen aan toonder en schuldbrieven aan toonder kunnen worden afgegeven;

- de vennootschappelijke overeenkomst wordt namens de vennootschap door iedere bestuurder (en iedere eventuele commissaris) ondertekend.

Het bestuur moet bovendien ten kantore van het handelsregister opgaaf doen van het bestaan van een vennootschappelijke overeenkomst, maar de overeenkomst zelf hoeft niet aldaar te worden neergelegd. De vennootschappelijke overeenkomst is dus geen openbaar document. Uitdrukkelijk is in de Curaçaose regeling opgenomen dat bepalingen in een vennootschappelijke overeenkomst hetzelfde rechtsgevolg hebben als statutaire bepalingen, voor zover niet anders uit de wet, de statuten of de vennootschappelijke overeenkomst zelf voortvloeit. ${ }^{18}$

Tot slot nog de volgende vraag: kan doorwerking alleen worden aanvaard door hen die de contractuele visie aanhangen? Het antwoord hierop luidt onzes inziens ontkennend. De institutionele visie sluit geenszins uit dat aan aandeelhoudersovereenkomsten vennootschappelijke werking toekomt. ${ }^{19}$

\section{Dwingend vennootschapsrecht en buitenstatutaire regelingen}

Voor een goed begrip van doorwerking van contractuele afspraken in de vennootschappelijke sfeer is het noodzakelijk stil te staan bij twee voorvragen: in hoeverre is het vennootschapsrecht van dwingend recht; en welke regelingen moeten in de statuten worden opgenomen en welke mogen (ook) in een overeenkomst worden opgenomen? Deze vragen worden in deze paragraaf besproken. Om dat goed te kunnen doen zal daarvóór kort worden stilgestaan bij het rechtskarakter en de uitleg van statuten, de kwestie of bij unaniem aandeelhoudersbesluit van de statuten kan worden afgeweken en de discussie over 'incorporation by reference'.

I7 Art. 2:I27/227 lid 3 Curaçao BW.

I8 Art. 2:I27/227 lid 4 Curaçao BW. Zie voor stemovereenkomsten naar Belgisch recht H. Braeckmans en R. Houben, Handboek vennootschapsrecht, Antwerpen: Intersentia 2012, p. 430-436.

Aldus reeds Van Schilfgaarde/Winter 2003, nr. I. 
Eerst nog een terminologisch punt. Wat betekent het als wordt gezegd dat er sprake is van vennootschappelijke werking of doorwerking van een overeenkomst binnen (in) de vennootschappelijke sfeer of binnen het vennootschappelijk kader, of dat een aandeelhoudersovereenkomst vennootschapsrechtelijke gevolgen heeft? ${ }^{20}$ Het gaat daarbij in de eerste plaats om de afdwingbaarheid of tegenwerpbaarheid van een contractuele bepaling binnen de vennootschappelijke orde, dat wil zeggen jegens de aandeelhouders en de vennootschap (en de leden van haar organen). ${ }^{21}$ Het hangt van de aard van de afspraak af op welke manier de afdwingbaarheid binnen het vennootschappelijk kader werking kan krijgen. Een afspraak inzake de uitoefening van het stemrecht beoogt effect te hebben op de besluitvorming, dus daar doet zich de vraag voor of de afspraak met gevolgen voor de besluitvorming afdwingbaar is. Andere dan stemafspraken (bijvoorbeeld over prijsbepaling) dienen tussen de aandeelhouders onderling en soms (mede) jegens de vennootschap te worden afgedwongen.

De minister noemde in de toelichting bij het wetsvoorstel vereenvoudiging en flexibilisering bv-recht ${ }^{22}$ met betrekking tot statutaire bepalingen nog twee andere vormen van 'doorwerking' binnen de vennootschappelijke orde (vennootschappelijke gevolgen): een besluit van een orgaan van de vennootschap is nietig als het in strijd met de wet of de statuten is genomen; ${ }^{23}$ en statutaire voorschriften zijn verbindend zonder dat ze uitdrukkelijk aanvaard hoeven te zijn door de betrokkenen. ${ }^{24}$ Waar wij hieronder spreken van vennootschappelijke werking zullen wij zoveel mogelijk aangeven welke vorm van doorwerking is bedoeld. ${ }^{25}$

\section{I Rechtskarakter en uitleg van statuten}

Zoals hiervoor reeds opgemerkt gold de nv tot halverwege de jaren vijftig van de vorige eeuw als een gekwalificeerde maatschap. Deze contractuele visie impliceerde tevens dat de statuten van de nv werden beschouwd als contractuele regels. ${ }^{26}$

Wij spreken hieronder verder van vennootschappelijke werking of vennootschappelijke doorwerking.

2I De term tegenwerpbaarheid wordt gebruikt door Blanco Fernández in zijn noot onder Rb. Den Haag I augustus 2012, JOR 2012/286 (Vanka-Kawat). Hieronder gebruiken wij deze twee termen als synoniemen.

22 Kamerstukken II 2006/07, 3I 058, nr. 3, p. I5-17.

23 Art. 2:I4 BW. Een besluit genomen in strijd met een reglement (zie daarover verder hieronder) is vernietigbaar (art. 2:15 lid I, onder c, BW). Verder zijn opvolgende bestuurders en commissarissen gebonden aan een reglement voor het bestuur c.q. de raad van commissarissen. In zoverre kan worden gezegd dat ook een reglement vennootschappelijke werking heeft.

24 Kamerstukken II 2009/ro, 32 426, nr. 3, p. 2-4.

25 Voorbeelden van andere vormen van doorwerking van contractenrecht binnen het vennootschappelijke kader zijn: in de statuten zelf vastgelegde verbintenissen van aandeelhouders onderling (bijv. art. 2:192 BW); bepaalde regelingen of wijziging van bepaalde statutaire regelingen die een aandeelhouder niet tegen zijn wil kunnen worden opgelegd (bijv. art. 2:192 lid 3 BW); een tendens tot geliikschakeling van de interpretatiemaatstaf voor overeenkomsten (de zogenoemde Haviltex-norm) bij de interpretatie van statuten van persoonsgebonden vennootschappen (zie daarover verder hieronder); 'inkleuring' van de zorgvuldigheidsnorm van art. 2:8 $\mathrm{BW}$ door de inhoud van een aandeelhoudersovereenkomst (zie o.a. OK 30 december 2008, JOR 2009/128 (Sunergy)). 
Dit veranderde toen de institutionele theorie in zwang kwam. In de klassieke opvatting van deze theorie wordt de status van statuten doorgaans omschreven als volgt:

'het eigen, niet contractuele rechtsregime van de vennootschap als rechtspersoon, waaraan de oprichters, de later toetredende aandeelhouders en ook de vennootschap zelf zijn gebonden.'27

Hieruit wordt doorgaans afgeleid dat de statuten een objectiefrechtelijk karakter hebben. Het kenmerk van objectiefrechtelijke bepalingen is immers dat zij, net zoals wettelijke bepalingen, geldend zijn voor de betrokken rechtsgenoten, ongeacht de vraag of deze rechtsgenoten de betreffende bepalingen hebben aanvaard. Ter staving van het objectiefrechtelijke karakter van statuten wordt in de literatuur beargumenteerd dat de statuten niet alleen rechten en verplichtingen in het leven roepen voor degenen die de statuten vaststelden, maar ook ten aanzien van degenen die later tot de vennootschap toetreden. ${ }^{28}$ Een aanvullend argument is dat degene die toetreedt tot een vennootschap zich niet slechts onderwerpt aan de bestaande regels maar ook aan eventuele toekomstige wijzigingen daarvan. Vaak wordt aan een en ander de conclusie verbonden dat de gelding van de statuten zelfs niet met instemming van alle aandeelhouders kan worden doorbroken. Wij komen op deze kwestie hierna in deze paragraaf terug.

Op de visie dat statuten een objectiefrechtelijk karakter hebben, kan het een en ander worden afgedongen. In de situatie dat de aandeelhouders de inhoud van hun samenwerkingsafspraken uitonderhandelen en zij specifiek op hun samenwerking toegespitste bepalingen opnemen in overeenkomst en statuten, kan slecht gesproken worden van statutaire regelingen met een objectiefrechtelijk karakter. Het staat bovendien een ieder vrij wel of niet toe te treden tot een vennootschap. Indien men de rechten en verplichtingen in de statuten niet wenst te aanvaarden zal geen toetreding tot de vennootschap plaatsvinden terwijl deze toetreding wel zal volgen indien de statutaire rechten en verplichtingen worden aanvaard. In zoverre is er geen verschil met het niet al dan niet aanvaarden van contractuele rechten en verplichtingen.

In het Nederlandse recht geldt dat de bedoeling van partijen het uitgangspunt is bij de uitleg van overeenkomsten. Indien de letterlijke tekst van de overeenkomst niet strookt met de bedoeling van partijen dan prevaleert in beginsel de bedoeling boven de letter. Het Haviltex-arrest uit I98I geldt nog steeds als het standaardarrest voor deze materie. De Hoge Raad besliste dat het bij contractsuitleg aankomt op de zin die partijen in de gegeven omstandigheden over en weer redelijkerwijs aan de contractuele bepalingen mochten toekennen en op hetgeen zij te dien aanzien redelijkerwijs van elkaar mochten verwachten. In 1993 oordeelde de Hoge Raad dat bij de uitleg van de cao-bepalingen in beginsel moet worden uitgegaan van de bewoordingen van de bepalingen, gelezen in het licht van de gehele tekst van de

27 Asser/Maeijer 2-III* 2000, nr. 56.

28 Zie bijvoorbeeld Asser/Van der Grinten/Maeijer 2-II^ I997, nr. 36. 
overeenkomst. ${ }^{29}$ Het duurde tot 2004 voordat de Hoge Raad duidelijk kon maken dat tussen de Haviltex-norm en de Cao-norm geen tegenstelling bestaat maar sprake is van een glijdende schaal. Uit DSM-Chemie/Fox ${ }^{30}$ kan immers worden geconcludeerd dat indien de overeenkomst bestemd is om de rechtspositie van derden te beïnvloeden de glijdende schaal meer neigt naar de tekst van de overeenkomst. Hebben partijen echter invloed gehad op de totstandkoming en inhoud van de overeenkomst terwijl het derdenbelang ontbreekt dan ligt de nadruk meer op de partijbedoeling. Naar aanleiding van HR ig januari 2007, NJ 2007, 575 (Meyer Europe/PontMeyer) en HR 29 juni 2007, NJ 2007, 567 (Derksen/Homburg) leek het er even op dat de Hoge Raad een nieuwe rechtsregel had geïntroduceerd, inhoudende dat bij de uitleg van commerciële contracten tussen professionele partijen die zich bij het opstellen van het contract door juridische adviseurs hebben laten bijstaan, als uitgangspunt beslissend gewicht dient te worden toegekend aan de meest voor de hand liggende taalkundige betekenis van de bewoordingen van het contract. Recent heeft de Hoge Raad echter duidelijk gemaakt dat ook indien het gaat om de uitleg van commerciële contracten de omstandigheden van het geval kunnen meebrengen dat een andere dan de taalkundige betekenis aan de bepalingen van de overeenkomst moet worden gehecht. Wij doelen op het arrest LundiForm/Mexx ${ }^{3 \mathrm{I}}$ waarin de Hoge Raad herbevestigt dat bij de uitleg van commerciële contracten de Haviltex-norm het uitgangspunt is en blijft.

Wij zouden menen dat de Haviltex-norm ook dient te worden gebruikt bij de uitleg van de statuten van een persoonsgebonden bv waarvan de aandeelhouders bij het aangaan van een samenwerking niet alleen de inhoud van de aandeelhoudersovereenkomst maar tevens de inhoud van de statuten hebben uitonderhandeld, tenzij het bepalingen betreft waarbij belangen van derden zijn betrokken. Bij de uitleg van de statuten in dergelijke omstandigheden ligt het voor de hand groot gewicht toe te kennen aan de betekenis van de corresponderende bepalingen die in de aandeelhoudersovereenkomst zijn opgenomen. In de inner circle van de vennootschap is geen noodzaak voor objectieve uitleg. In de literatuur wordt doorgaans echter uitgegaan van objectieve uitleg van statuten zonder naar de aard van de vennootschap te differentiëren. ${ }^{32}$ Hierbij wordt met name inspiratie geput uit de door de Hoge Raad geformuleerde Cao-norm (waarbij zij opgemerkt dat de literatuur van vóór de recente uitspraak inzake Lundiform/Mexx dateert). Wij zijn van mening dat toepassing van de Cao-norm geen recht doet aan de omstandigheden waarin aandeelhouders in persoonsgebonden vennootschappen zich doorgaans bevinden. De Haviltex-norm zou ook hier het uitgangspunt moeten zijn.

Een reglement ten slotte is een document waarin een orgaan van de vennootschap zijn functioneren kan vastleggen. Algemeen wordt aangenomen dat, als de statuten zulks bepalen, een reglement ook door een ander orgaan kan worden vastgesteld, bijvoorbeeld een reglement van het bestuur door de algemene vergadering. Boek 2

29 HR I7 september I993, NJ I994, I73, m.nt. PAS (Gerritse/Hydro Agri Sluiskil).

30 HR 20 februari 2004, NJ 2005, 493, m.nt. C.E. du Perron.

3 I HR 5 april 20I3, NJ 20I3, 2I4 (Lundiform/Mexx).

32 Asser/Van Solinge \& Nieuwe Weme 2-IIa* 2013, nr. 260. 
bevat slechts enkele bepalingen betreffende het reglement, de belangrijkste daarvan is dat een besluit genomen in strijd met een reglement vernietigbaar is (artikel 2:I5 lid I, onder c, BW). Door de algemene vergadering (unaniem) vastgestelde reglementen en genomen besluiten zijn evenals aandeelhoudersovereenkomsten wilsuitingen van de gezamenlijke aandeelhouders. Zij moeten onzes inziens eveneens conform de Haviltex-norm worden uitgelegd.

\subsection{De discussie over het unanieme aandeelhoudersbesluit in strijd met de statuten}

Een door de aandeelhouders unaniem genomen besluit bevat een wilsuiting van alle aandeelhouders en verschilt in dit opzicht niet van een aandeelhoudersovereenkomst. ${ }^{33}$ Hier doet zich echter een probleem voor. De Hoge Raad heeft in de eerste helft van de vorige eeuw in enkele uitspraken bepaald dat een statutaire regel zelfs niet door een unaniem aandeelhoudersbesluit terzijde kan worden gesteld. ${ }^{34}$ Dit lijkt nog steeds de heersende leer te zijn. ${ }^{35}$ Met andere woorden: een dergelijk unaniem besluit is in beginsel nietig wegens strijd met de statuten. ${ }^{36}$ Dit verschil in rechtsgevolg leidt tot de volgende paradox: als de aandeelhouders een van de statuten afwijkende gezamenlijke wilsuiting vastleggen in de vorm van een besluit van de algemene vergadering, is dat besluit in de heersende opvatting nietig; leggen zij die wilsovereenstemming vast in een overeenkomst, dan is deze geldig (behoudens strijd met dwingend recht). Wij zouden menen dat ook als het besluit nietig is, de erin vervatte wilsovereenstemming in stand blijft. ${ }^{37}$

De regel dat een unaniem aandeelhoudersbesluit waarin wordt afgeweken van de statuten, nietig is, dient onzes inziens in de context van persoonsgebonden vennootschappen geen toepassing te vinden. Deze benadering doet onzes inziens meer recht aan het karakter van persoonsgebonden vennootschappen. ${ }^{8}$ Meinema bepleit dat artikel 3:40 BW (strijd met een dwingende wetsbepaling leidt slechts tot vernietigbaarheid als zij uitsluitend strekt ter bescherming van een der partijen) analogisch van toepassing is op in strijd met de statuten genomen besluiten die uitsluitend

33 Het Engelse recht kwalificeert besluiten en statuten als bijzondere overeenkomsten; zie hierover uitgebreid M. Meinema, Dwingend recht voor de besloten vennootschap (diss. Maastricht) (Serie Instituut voor Ondernemingsrecht, deel 43), Deventer: Kluwer 2003, p. I42.

34 Onder meer HR 8 april I938, NJ I938, I076 en HR I6 juni I944, NJ I944, 443.

35 Zie onder meer Asser/Maeijer/Van Solinge \& Nieuwe Weme 2-II^ 2009, nr. $32 \mathrm{I}$.

36 De wet geeft enkele uitzonderingen, onder andere in de vorm van heling van oproepingsgebreken; zie verder Meinema 2003, p. I45-I47.

37 Volgens Meinema 2003, p. 157-I58, is conversie (art. 3:42 BW) mogelijk. Men kan zich afvragen of conversie strikt genomen op deze situatie ziet.

$3^{8}$ In deze richting lijkt ook een oude uitspraak te gaan van de belastingkamer van de Hoge Raad, waarin wordt overwogen dat 'generlei wetsbepaling [voorschrijft] dat ieder besluit in afwijking van de Statuten genomen, steeds nietig is, doch het denkbaar is dat de bijzondere aard van een statutair voorschrift in verband met het belang, dat het beoogt te beschermen, afwijking met instemming van alle aandeelhouders zou kunnen toelaten.' HR I4 december 1932, W. I2872, zoals geciteerd door Blanco Fernández, 'Rechtmatigheidsgrenzen van stemovereenkomsten' WPNR 2005, p. 520. In dit artikel betoont de auteur zich overigens zeer kritisch over deze rigide regel. 
de belangen van aandeelhouders raken en dus niet strekken tot bescherming van andere bij de vennootschap betrokkenen. ${ }^{39} \mathrm{Wij}$ menen dat hier een verdergaand standpunt kan worden ingenomen. In feite gaat het hier om een ontheffing van een statutaire regel. $4^{\circ}$ Dit mechanisme is met betrekking tot ontheffing van statutaire verplichtingen en eisen sinds I oktober 2012 met zoveel woorden in de wet opgenomen. ${ }^{4 \mathrm{I}} \mathrm{Wij}$ zouden willen aannemen dat een dergelijke ontheffing ook met betrekking tot andere statutaire bepalingen mogelijk is, dat wil zeggen dat de statuten kunnen bepalen dat een statutaire bepaling tijdelijk buiten werking kan worden gesteld door een besluit van de gezamenlijke aandeelhouders..$^{2}$

\subsection{De discussie over 'incorporation by reference'}

De discussie over incorporation by reference is diffuus omdat hiermee door verschillende schrijvers verschillende concepten worden bedoeld. Wij gaan van de volgende omschrijving uit: het in de statuten verwijzen naar een aandeelhoudersovereenkomst. De vraag die werd opgeworpen is of door een dergelijke verwijzing de inhoud van de aandeelhoudersovereenkomst een 'vennootschapsrechtelijk kader' of 'vennootschappelijke werking' krijgt. De minister beantwoordde deze vraag als volgt:

'Het verbod op incorporation by reference is erop gericht te voorkomen dat toekomstige aandeelhouders automatisch gebonden zouden worden aan regelingen die niet in de statuten zijn opgenomen en daardoor niet naar buiten toe kenbaar zijn. De voorgestelde wettelijke regeling staat er niet aan in de weg dat de statuten bepalen dat de niet-naleving van een aandeelhoudersovereenkomst wordt gesanctioneerd met de opschorting van aandeelhoudersrechten. De materiële inhoud van de aandeelhoudersovereenkomst wordt daarmee nog geen onderdeel van het vennootschapsrechtelijke kader. Omdat toekomstige aandeelhouders niet automatisch zijn gebonden door de overeenkomst en de daaraan verbonden sancties, is het niet bezwaarlijk dat de aandeelhoudersovereenkomst niet in de statuten zelfstaat en daardoor voor derden niet kenbaar is." 43

39 Meinema 2003, p. I48-I49. De instemming van de aandeelhouders met het besluit geldt dan, aldus Meinema, als verwerking van het recht om vernietiging van het besluit te vorderen.

40 In Duitsland als leerstuk bekend onder de naam Satzungsdurchbrechung. Zie hierover Meinema 2003, p. I63-I66.

4I Zie art. 2:I92 lid 2, laatste volzin, BW, luidend: 'De statuten kunnen voorts bepalen dat een daartoe in de statuten aangewezen orgaan van de vennootschap ontheffing kan verlenen van een statutaire verplichting of eis.'

42 Vgl. Rb. Middelburg (pres.) I4 april I998, JOR 2000/25 (VenV), besproken in paragraaf 3. Als in een unaniem aandeelhoudersbesluit is besloten een bepaalde statutaire regeling tijdelijk buiten werking te stellen terwijl een dergelijk mechanisme niet in de statuten is vastgelegd, zou onzes inziens een beroep door een aandeelhouder op de statutaire regeling naar maatstaven van redelijkheid en billijkheid onaanvaardbaar zijn (art. 2:8 lid 2 BW). Dat de wilsuiting van de gezamenlijke aandeelhouders daadwerkelijk op tijdelijke buitenwerkingstelling van de statutaire bepaling in kwestie is gericht, kan in de preambule van het desbetreffende besluit worden aangegeven.

43 Kamerstukken II 2006/07, 3I 058, nr. 6, p. 2 en p. 20. 
Deze inderdaad niet geheel duidelijke passage (en de daarop volgende alinea) heeft tot veel verwarring geleid. ${ }^{44} \mathrm{Na}$ herlezing ervan menen wij dat er niets in staat dat onjuist is en de minister hier slechts het volgende heeft bedoeld:

I. aan niet-naleving van een aandeelhoudersovereenkomst kunnen statutair sancties worden verbonden zoals opschorting van stemrecht of een plicht tot aanbieding van de aandelen;

2. de statutaire sancties gelden alleen voor de aandeelhouders (en hun eventuele rechtsopvolgers) die partij bij de overeenkomst zijn (c.q. worden);

3. een opvolgend aandeelhouder is niet gebonden aan een aandeelhoudersovereenkomst door het enkele feit dat in de statuten naar de overeenkomst wordt verwezen. 45

\subsection{Het dwingendrechtelijk uitgangspunt van het vennootschapsrecht}

Het lijdt geen twijfel dat contractuele afwijking van regelend vennootschapsrecht mogelijk is. Dit is nog eens bevestigd door de minister in het kader van de parlementaire behandeling van de flexibilisering van het bv-recht:

'[D]e vraag [is] aan de orde gesteld of het in de voorgestelde regeling nog steeds mogelijk is om afwijkingen van wettelijke bepalingen van regelend recht in plaats van in de statuten contractueel vast te leggen. Uit het bovenstaande moge blijken dat het antwoord hierop bevestigend is. Daar waar de wet bepaalt dat de statuten kunnen voorzien in afwijkende of aanvullende regelingen, betekent dit niet dat dergelijke regelingen niet contractueel kunnen worden vastgelegd.'46

Wij delen dit standpunt van de minister. ${ }^{47}$ Bezien wij thans de veel lastiger vraag of en in hoeverre afwijking van dwingend vennootschapsrecht mogelijk is.

Het dwingendrechtelijk 'uitgangspunt' van het Nederlandse vennootschapsrecht is neergelegd in artikel 2:25 BW, dat voor alle in Boek 2 gereguleerde rechtspersonen

44 Zie met name P.J. Dortmond, 'Wijzigingen in het wetsontwerp flexibilisering bv-recht', Ondernemingsrecht 2009, p. 33-34; E.J.J. van der Heijden en W.C.L. van der Grinten, bewerkt door P.J. Dortmond, Handboek voor de naamloze en de besloten vennootschap, Deventer: Kluwer 20I3, p. 44I (hierna: Dortmond 2013); Cremers, 'Hoe flexibiliseer je een bv?', Ondernemingsrecht 2012, p. 613; Vorst, 'Aandeelhoudersovereenkomst of statuten: balanceren voor de praktijkjurist', WPNR 2013/6979.

45 In soortgelijke zin P. van Schilfgaarde, 'Statuten zonder bezwaar', WPNR 2002, p. 64I. Zie ook Dortmond 2009, p. 33 en Dortmond 2013, nr. 217.2. Anders (vóór de geciteerde 'verduidelijking' door de minister): J.A.M. ten Berg, 'Statuten versus aandeelhoudersovereenkomsten', in: W. Bosse e.a. (red.), Statuten zonder bezwaar (Preadvies Koninklijke Notariële Beroepsorganisatie), Den Haag: Koninklijke Vermande 2002, p. I9I-I92, p. I86 en F.K. Buijn, 'Statuten: terug naar de overeenkomst?', Ondernemingsrecht I999, 5, p. I20.

46 Kamerstukken II 2006/07, 3 I 058, nr. 3, p. I5-I7.

47 W.J.M. van Veen, Boek 2 BW, statuten en aandeelhoudersovereenkomsten (ZIFO-reeks, deel 2), Deventer: Kluwer 20II, p. I3 stelt dat het gezien de conceptuele verschillen en de wettelijke systematiek als het gaat om de reikwijdte van Boek 2 niet zo voor de hand ligt om statuten en aandeelhoudersovereenkomsten op één lijn te stellen en dat 'op grond van die verschillen' de toelaatbaarheid van aandeelhoudersovereenkomsten niet zo problematisch behoeft te zijn. Deze redenering onderschrijven wij niet. 
geldt. Artikel 2:25 luidt: 'Van de bepalingen van dit boek kan slechts worden afgeweken, voor zover dat uit de wet blijkt.' Het is in het kader van dit preadvies niet mogelijk en ook niet nodig om de gehele discussie over de betekenis van deze lapidaire bepaling weer te geven. ${ }^{4}{ }^{8} \mathrm{Wij}$ volstaan hier met de constatering dat in de vorige eeuw de gangbare opvatting was dat afwijking van een bepaling van Boek 2 slechts mogelijk is indien en voor zover de wet dit expliciet aangeeft.

Daarnaast speelt artikel 3:40 BW een belangrijke rol. Dat artikel luidt: 'Strijd met een dwingende wetsbepaling leidt tot nietigheid van de rechtshandeling maar slechts tot vernietigbaarheid indien de bepaling uitsluitend strekt ter bescherming van één der partijen, tenzij uit de strekking van de bepaling anders voortvloeit.' Artikel 3:40 BW geldt voor alle civielrechtelijke rechtshandelingen, dus niet alleen voor overeenkomsten maar ook voor statutaire bepalingen en besluiten van vennootschapsorganen. Met betrekking tot besluiten is het eerste deel van artikel 3:40 verwoord in artikel 2:I4 lid I BW: 'Een besluit van een orgaan van een rechtspersoon dat in strijd is met de wet of de statuten, is nietig, tenzij uit de wet iets anders voortvloeit.'

Een contractuele bepaling kan nietig zijn op grond van artikel 3:40 BW maar niet op grond van artikel 2:25 BW. ${ }^{49}$ Er is sprake van een zekere mate van inkleuring (wisselwerking) of overlap van beide bepalingen doordat bepaalde vennootschappelijke normen eveneens doorwerken in of zelfs ontleend zijn aan het verbintenissenrecht, of, omgekeerd, doordat overeenkomsten tussen aandeelhouders op een bepaalde wijze doorwerken in statuten..$^{\circ}$ Een problematische spanning ontstaat in het geval een bepaling in de statuten nietig is op grond van artikel 2:25 maar dezelfde bepaling in een contract niet nietig (c.q. vernietigbaar) is op grond van artikel 3:40.5 Hieronder zal blijken dat deze spanning in persoonsgebonden vennootschappen niet aanwezig behoeft te zijn.

48 Zie voor een uitvoerige behandeling van art. 2:25 BW en zijn voorlopers de dissertatie van Meinema (onder meer p. 23-3I), met literatuurverwijzingen.

49 Dit formele onderscheid lost zich op in een geval dat een overeenkomst in strijd is met de (vennootschappelijke) openbare orde en dat betekent dus strijd met dwingendrechtelijke regels van Boek 2. Vgl. Timmerman, Verslag van het congres 'Ondernemingsrechtelijke contracten' gehouden op 8 en 9 maart 199 I te Groningen, in: L. Timmerman e.a. (red.), Ondernemingsrechtelijke contracten (Serie IvO, deel I4): Deventer: Kluwer I99I, p. I, die stelt dat de dwingende aard van vennootschapsrechtelijke regels kan meebrengen dat het niet mogelijk geacht moet worden dat bij overeenkomst ervan wordt afgeweken. Bij dit soort formuleringen komt het onzes inziens, zoals vaker bij deze materie, aan op het vinden van concrete voorbeelden die duidelijk maken wat er wel en wat er niet onder valt. Zo zal niemand betwijfelen dat een afspraak dat het bestuur toezicht houdt op de raad van commissarissen of dat de ondernemingsraad bevoegd is tot uitgifte van aandelen nietig is wegens strijd met de openbare (vennootschappelijke) orde. Zie over strijd van stemovereenkomsten met de vennootschappelijke (openbare) orde paragraaf 3.I.

50 Zie ook Meinema 2003, p. I4.

5I Zie ook H.J. de Kluiver en M. Meinema, 'Dwingend vennootschapsrecht na de Wet herziening preventief toezicht en de mogelijkheden van statutaire of contractuele afwijking en aanvulling', WPNR 2002, p. 649-65I. In dit opzicht zou men art. 2:25 BW een specialis van art. 3:40 BW kunnen noemen. Het valt buiten het kader van dit preadvies om de relatie tussen deze bepalingen uitgebreid te bespreken. 
Terug naar het dwingendrechtelijk uitgangpunt van het vennootschapsrecht. De Kluiver en Meinema hebben in 2002 op overtuigende wijze betoogd dat de verankering van het dwingendrechtelijk uitgangspunt in artikel 2:25 BW primair een wetgevingstechniek is; $5^{22}$ dat aanvulling daarop of afwijking daarvan mogelijk is als deze mogelijkheid uit de desbetreffende wettelijke bepaling blijkt; en dat doel en strekking van iedere wettelijke bepaling het kader aangeven waarbinnen eventuele afwijkingen mogelijk zijn. Zij verwoorden dit op de volgende kernachtige wijze: 'De reikwijdte van art. 2:25 staat en valt derhalve met de dwingende kracht van de bepalingen zelf.' ${ }^{3}$ Zij wijzen er verder op dat in de rechtspraak en de literatuur ervan wordt uitgegaan dat weinig expliciet verboden is. Ook het zwijgen van de wet kan worden zien als ruimte voor aanvulling indien uit doel en strekking van de bepaling niets anders voortvloeit. ${ }^{4}$ In de praktijk heerst eveneens de opvatting dat de wettelijke bepalingen in contractueel opzicht veel toestaan. ${ }^{55}$ Ook Timmerman is van oordeel dat het dwingendrechtelijk karakter van een wettelijke bepaling restrictief dient te worden uitgelegd teneinde te bewerkstelligen dat rechtsgeldig is een statutaire of contractuele bepaling die de joint venture-partners wenselijk achten..$^{56}$

Deze 'moderne' visie op het dwingendrechtelijk uitgangspunt van het vennootschapsrecht komt ook naar voren in de parlementaire geschiedenis van het wetsvoorstel tot flexibilisering van het bv-recht. De Expertgroep die het wetsvoorstel voorbereidde, heeft zich gebogen over de vraag of de aard van het rechtspersonenrecht primair dwingend of primair regelend recht dient te zijn. Voor de Expertgroep is bij de gedachtevorming over een regeling van de bv steeds meer het laatstgenoemde uitgangspunt gaan overheersen. $\mathrm{Zij}$ betoogde dat voor de bv de toepasselijkheid van artikel 2:25 BW heroverweging verdiende..$^{57}$ Ook in de literatuur werd afschaffing van het dwingendrechtelijke uitgangspunt van het vennootschapsrecht bepleit..$^{8}$

52 Deze analyse is overgenomen in het verderop in deze paragraaf gegeven citaat van de minister van Justitie.

53 Zie De Kluiver en Meinema, WPNR 2002, p. 649-650. De Kluiver en Meinema maken een onderscheid tussen aanvulling en afwijking van dwingendrechtelijke bepalingen. Dat onderscheid is soms moeilijk te maken. In dit preadvies gebruiken wij hoofdzakelijk het begrip afwijking, waaronder wij dan ook aanvulling verstaan.

54 Meinema 2003, p. 30. Het overtuigende, door De Kluiver en Meinema genoemde, voorbeeld is de bindende voordracht als wettelijk toegestane beperking van de benoemingsbevoegdheid. In de vorige eeuw meende men dat dit de enige toegestane beperking was (zie bijvoorbeeld nog Asser/ Maeijer 2-III ${ }^{\star}$ 2000, nr. 313). De Kluiver en Meinema wijzen er echter terecht op dat daarnaast ook andere inperkingen in de praktijk en in de heersende opvatting geoorloofd zijn, zoals unanimiteit met volledig quorum of goedkeuring van derden. Aldus ook Asser/Maeijer/Van Solinge \& Nieuwe Weme 2-II* 2009, nr. 432.

55 De Kluiver en Meinema, WPNR 2002, p. 65I. Ze voegen daaraan toe dat de theorie en de rechtspraak aan de contractuele afspraken wel voorwaarden stelt die met name beogen 'een zekere mate van bepaaldheid aan de verplichtingen te verbinden'.

56 L. Timmerman, 'Het krakende gebouw in het vennootschapsrecht', TVVS I995, p. I8r. Vgl. ook Van Veen 20II, p. Io. Elders zegt Timmerman (I99I, nr. I4, p. IIo): 'Ik ben het met Van der Grinten eens dat het dwingende karakter van het vennootschapsrecht slechts bij uiterste noodzaak zwaar aangezet moet worden.'

57 Rapport van de Expertgroep d.d. 6 mei 2006 in: Van den Ingh en Nowak 2006, p. 178-I79.

58 Zie o.a. L. Timmerman, Onderstromen in het privaatrechtelijke rechtspersonenrecht (Preadvies NJV 2000), Deventer: Kluwer 2000, M.W. den Boogert, 'Aanpassing van Boek 2 BW voor jointventure-doeleinden?', AA I995/5, p. 79. 
Bij de parlementaire behandeling van de invoering van de wet flexibilisering bvrecht merkte de minister van Justitie op:

'Om een aantal redenen is ervoor gekozen om het dwingendrechtelijk uitgangspunt bij de bv te handhaven. Een systeem van regelend recht zou afwijken van de regeling voor de overige rechtspersonen in Boek 2 BW. De regels in het algemeen deel van Boek 2 BW zouden dan van regelend recht zijn voor de bv en dwingendrechtelijk gelden voor de overige rechtspersonen. Wetssystematisch is dit geen wenselijke uitkomst. (...) De commissie vennootschapsrecht ${ }^{59}$ heeft erop gewezen dat de vraag of de wettelijke regeling moet uitgaan van regelend dan wel van dwingend recht in wezen een vraag is van wetgevingstechniek. De invoering van meer regelend recht voor de bv kan volgens de commissie ook gebeuren met handhaving van de thans geldende systematiek. In die systematiek rechtvaardigt het meer institutionele karakter van de rechtspersonen in Boek $2 \mathrm{BW}$ volgens de commissie de toepassing van een in beginsel dwingend regime. De ruimte om in de statuten van het dwingendrechtelijke uitgangspunt af te wijken neemt met dit wetsvoorstel op een groot aantal punten toe. ${ }^{60}$

Zien wij het goed, dan is in bovenstaande passage sprake van een restrictieve uitleg (met betrekking tot het bv-recht) van het dwingendrechtelijke uitgangspunt van artikel 2:25 BW, in die zin dat van een bepaling kan worden afgeweken tenzij zij naar haar strekking van dwingend recht is. ${ }^{6 \mathrm{I}}$ Deze uitleg komt onzes inziens dicht bij de in de literatuur bepleite omkering van het dwingendrechtelijk uitgangspunt, in die zin dat het dwingendrechtelijk karakter van een bepaling telkens dient te worden aangegeven (en gerechtvaardigd). ${ }^{6}$

\subsection{Gronden voor dwingend vennootschapsrecht}

Over de gronden voor (ofwel de functies van) dwingend vennootschapsrecht is veel geschreven. Hieronder volgt een korte bespreking van de materie voor zover voor dit preadvies dienstig. Door de hieronder gemaakte indeling heen loopt het onderscheid tussen twee 'aspecten' van dwingend recht: is een regel in die zin van dwingend recht dat op geen enkele wijze ervan kan worden afgeweken; en als afwijking is toegelaten, dient de afwijking dan dwingendrechtelijk (lees: op straffe van ongeldigheid ervan) in de statuten te worden opgenomen? ${ }^{63}$

59 [door preadviseurs ingevoegde voetnoot] Rapport van de commissie vennootschapsrecht d.d. 24 juni 2004, opgenomen in: Van den Ingh en Nowak 2006, p. 293-294. De commissie zegt letterlijk [cursivering van de preadviseurs]: 'Naar de mening van de commissie dient de toepasselijkheid van artikel 2:25 BW op de BV te worden gehandhaafd. De vraag of de wettelijke regeling moet uitgaan van regelend dan wel van dwingend recht is in wezen een vraag van wetgevingstechniek. De commissie stemt gaarne in met de wens van invoering van meer regelend recht voor de BV. Dat kan echter gebeuren met handhaving van de thans geldende systematiek, waarin de rechtspersonen van Boek $2 \mathrm{BW}$, die een meer institutioneel karakter vertonen, onderworpen zijn aan een in beginsel dwingend regime. Van dit regime kan dan worden afgeweken wanneer de wet daartoe ruimte biedt. Flexibilisering van het BV-recht betekent dat die ruimte zal toenemen.'

6o Kamerstukken II 2006/07, 3I 058, nr. 3, p. 6.

6I Zie ook Van Veen 20II, p. Io.

62 Zie voor een dergelijk pleidooi met name Timmerman 2000, p. I62.

63 Dit laatste aspect in verband met de zogenoemde openbaarheidsfunctie: zie hieronder. 
* Regels inzake de bescherming van bij de vennootschap betrokkenen ('waarborgfunctie')

De belangrijkste functie van dwingend vennootschapsrecht is het waarborgen van rechten van bij de vennootschap betrokkenen. Hieronder worden doorgaans verstaan: crediteuren, werknemers en (minderheids)aandeelhouders. ${ }^{64}$ Men kan verder denken aan de regels omtrent de geldigheid van besluiten. ${ }^{65}$ Het betreft hier dwingende regels die de wet geeft ter bescherming van de specifieke belangen van die groepen, in het bijzonder de regels inzake crediteurenbescherming, de vennootschapsrechtelijke medezeggenschapsregels en - als default - de uittreed- en geschillenregeling. Deze regels gelden ongeacht of ze in de statuten zijn vermeld. Afwijking van deze dwingendrechtelijke regels is niet mogelijk, behoudens in het volgende geval.

Als een bepaling uitsluitend strekt ter bescherming van (minderheids)aandeelhouders, kunnen dezen volgens de heersende opvatting afzien van de dwingendrechtelijke bescherming en derhalve ook anders overeenkomen. ${ }^{66}$ Deze mogelijkheid om van (de uitoefening van) de hun dwingendrechtelijk toekomende bevoegdheden af te zien, impliceert, zoals Meinema terecht constateert, dat het dwingendrechtelijk karakter ten opzichte van hen niet absoluut is, met andere woorden: dat ervan kan worden afgeweken. ${ }^{67}$ In een persoonsgebonden vennootschap hebben de aandeelhouders zich contractueel gebonden. De waarborgfunctie van dwingendrechtelijke bepalingen die alleen strekken tot bescherming van aandeelhouders speelt dan ook geen rol omdat het de aandeelhouders vrijstaat daarvan contractueel af te zien.

* Bepalingen omtrent de wettelijke bevoegdheidsverdeling en de duurzame structuur van de vennootschap

Van een aantal wettelijke regels inzake de wettelijke bevoegdheidsverdeling en de duurzame structuur van de vennootschap mag niet worden afgeweken. ${ }^{68}$ Zo berust

64 Timmerman I99I en Meinema 2003, p. 27-3I. Zie ook L. Timmerman, 'Is versoepeling van het n.v./b.v.-recht wenselijk?', TVVS I992, p. I65 en Van Schilfgaarde, 'De ontwikkeling van de rechtspersoon in het privaatrecht', NJB 2000, p. I094.

65 Zie ook Meinema 2003, p. 27-31, zij het dat de wet zelf hier afwijking toestaat bij de zogenoemde oproepingsgebreken; bovendien kunnen vernietigbare besluiten (zoals Meinema ook aangeeft) onaantastbaar worden gemaakt door af te zien van het recht om vernietiging te vorderen.

66 Zie hierover uitvoerig Meinema 2003, passim, en Ondernemingsrecht 2004, p. 36-40; De Kluiver en Meinema,WPNR 2002, p. 657. Zie ook reeds Timmerman I99I. De overeenkomst tot het afzien van de uitoefening van een recht dient volgens Meinema 'voldoende bepaalbaar' te zijn, dat wil zeggen, aldus Meinema, 'geconcretiseerd tot bepaalde omstandigheden of een bepaalde overzienbare periode'. Ten aanzien van het afzien van de uitoefening van stemrecht voegt Meinema daaraan toe 'voor bepaalde categorieën besluiten' (Meinema 2003, p. 55). Ze merkt daarbij op dat het 'doelbewust prijsgeven' van de mogelijkheid om een recht uit te oefenen impliceert dat dit prijsgeven geschiedt voor een overzienbare periode of voor een bepaalde categorie besluiten. Ons ontgaat die implicatie. Verder zij hier reeds opgemerkt dat Asser/Maeijer/Van Solinge \& Nieuwe Weme 2-IIa* $20{ }_{3} 3$ verder gaat met betrekking tot stemovereenkomsten (zie paragraaf $3 \mathrm{~B}$ hierna).

67 Meinema constateert vervolgens dat de aandeelhouders in het geval dwingende voorschriften zijn geschonden die tot vernietigbaarheid van het aldus genomen besluit leiden, bovendien kunnen afzien van de bevoegdheid om vernietiging te vorderen. Dit is op zich juist, maar gaat niet op bij schending van dwingendrechtelijke voorschriften die tot nietigheid van het genomen besluit leiden.

68 De term 'duurzame structuur' is van Timmerman I99I, p. 4. Daarnaast spreekt Timmerman van 'doelmatige inrichting' en 'eigen kenmerken' van de vennootschap (TVVS 1992, p. I65). Maeijer 
de bevoegdheid tot het vaststellen van de jaarrekening en tot statutenwijziging dwingendrechtelijk bij de algemene vergadering. ${ }^{69}$ Dwingend recht met betrekking tot de duurzame structuur kan worden gevonden in de regels omtrent oprichting, omzetting, fusie en splitsing van de vennootschap. ${ }^{70}$ Deze regels gelden ongeacht of ze in de statuten zijn vermeld en afwijking ervan is niet mogelijk, noch in de statuten, noch bij overeenkomst.

Door de wet toegestane regelingen inzake de bevoegdheidsverdeling en de duurzame structuur van de vennootschap mogen in beginsel alleen in de statuten worden neergelegd..$^{1}$ Dit wordt de 'openbaarheidsfunctie' of ook wel 'kenbaarheidsfunctie' van dwingend recht genoemd. ${ }^{72}$ Het gaat in de heersende opvatting om kenbaarheid door vastlegging van de desbetreffende regeling in een openbaar toegankelijk document (de statuten). De minister drukte het in het kader van de flexibilisering van het bv-recht aldus uit:

'Vanwege de vennootschapsrechtelijke gevolgen is het van belang dat een regeling duidelijk kenbaar is. Een statutaire regeling voldoet aan de eisen van kenbaarheid. ${ }^{73}$

'De statuten zijn bedoeld voor de afspraken die ook betekenis voor derden hebben en daarom voor hen kenbaar dienen te zijn. ${ }^{74}$

Een contractuele regeling terzake wordt in de heersende opvatting als nietig beschouwd. ${ }^{75}$ De duurzame structuur van de vennootschap mag alleen gewijzigd worden via openbaar gemaakte statuten en niet via een overeenkomst. ${ }^{6}$ Bevoegdheden dienen te worden uitgeoefend op basis van de bevoegdheidsverdeling in de wet (en in de statuten); er mag geen onzekerheid zijn welk orgaan welke bevoegdheid mag uitoefenen. ${ }^{7}$

spreekt van dwingende normen die wezenlijk zijn voor de inrichting en het functioneren van de vennootschap (J.M.M. Maeijer, 'De stemovereenkomst van aandeelhouders', in: J.M.M. Maeijer, P.W. van der Ploeg jr. en A.G. van Solinge (red.), Recht zo die gaat: opstellen aangeboden aan mr. P.W. van der Ploeg, Zwolle: W.E.J. Tjeenk Willink I976, p. I02).

69 In de zaak OK I6 april 2004, JOR 2004/I63 (NIBO), achtte de OK een contractuele bepaling dat een lening opeisbaar werd als de zittende bestuurders opstapten, een ongeoorloofde beperking van de bevoegdheid van de algemene vergadering.

70 De laatste categorie wordt ook wel het constitutieve vennootschapsrecht genoemd. Zie L. Timmerman, 'Gedragsrecht, belangenpluralisme en vereenvoudiging van het vennootschapsrecht: wat moet dwingend blijven in het vennootschapsrecht van de toekomst?' Ondernemingsrecht 2005, p. 6-7.

7 I Vgl. Meinema 2003, p. 27-3I.

72 De minister merkte terecht op: 'Vanwege de vennootschapsrechtelijke gevolgen is het van belang dat een regeling duidelijk kenbaar is. Een statutaire regeling voldoet aan de eisen van kenbaarheid. De inhoud van een regeling krachtens de statuten zal daarentegen minder of geheel niet kenbaar zijn.' Kamerstukken II 2006/07, 31 058, nr. 3, p. I5-I7.

73 Kamerstukken II 2006/07, 31 058, nr. 3, p. I5-17.

74 Kamerstukken II 2009/Io, 32 426, nr. 3, p. 2-4.

75 Zie bijvoorbeeld Buijn I999, p. I20 en Ten Berg, preadvies 2002, p. I87. Iets anders is dat partijen zich uiteraard contractueel kunnen verbinden het beoogde rechtsgevolg tot stand te zullen brengen.

76 Timmerman I99I, p. 4. Vgl. Van der Grinten 1976, p. 74, die stelt dat de vennootschap niet bij contract over haar eigen inrichting en structuur kan disponeren.

77 L. Timmerman, 'Structuur en gedragsnorm in de ondernemingsrechtspraak van de Hoge Raad', WPNR 2013/6969. Dit is zoals gezegd anders als de wet aangeeft dat een dergelijke regeling ook in een reglement kan worden vastgesteld. 
De reikwijdte van de openbaarheidsfunctie van dwingend recht roept veel vragen op en zal worden besproken in de volgende paragraaf.

* Dwingende normen voor bij de vennootschap betrokkenen

Bestuurders en commissarissen moeten in het belang van de vennootschap handelen; dit vloeit voort uit haar doelgebonden karakter. Een belangrijke component van het vennootschappelijk belang vormt het belang van de aandeelhouders. ${ }^{78}$ In een persoonsgebonden vennootschap zal het aandeelhoudersbelang prevaleren. Bestuurders en commissarissen moeten hun taak op een behoorlijke manier vervullen; doen ze dat niet dan gelden dwingende aansprakelijkheidsregels. Voorts geldt tussen alle bij de vennootschap betrokkenen de norm van redelijkheid en billijkheid. Ook deze regels gelden ongeacht of ze in de statuten zijn vermeld en afwijking ervan is niet mogelijk, noch in de statuten, noch bij overeenkomst.79

\section{* Bescherming van de dualistische structuur?}

In de institutionele opvatting wordt de nadruk gelegd op de dualistische (orgaan) structuur, waarmee wordt bedoeld de machtenscheiding tussen algemene vergadering en bestuur. ${ }^{80}$ De kern daarvan is een systeem van checks en balances tussen de vennootschapsorganen, hetgeen het voorhanden zijn van een goede regeling voor het intern functioneren van de vennootschapsorganen impliceert. ${ }^{8 \mathrm{r}}$ Men kan zich afvragen of deze functie in persoonsgebonden verhoudingen zo essentieel is dat zij een zelfstandig bestaansrecht heeft naast de bescherming van de duurzame structuur en de wettelijke bevoegdheidsverdeling van de vennootschap. ${ }^{82}$ Blanco Fernández heeft een meer beperkte omschrijving van het begrip dualisme voorgesteld: de bescherming van de vennootschapsleiding tegen usurpatie van hun dwingendrechtelijk toekomende bevoegdheden door de algemene vergadering. ${ }^{83}$ Wij kunnen ons, zeker in het geval van persoonsgebonden vennootschappen, in die beperkte omschrijving goed vinden. Bescherming van de dualistische structuur zal in het kader van dit preadvies dan ook niet als een functie van dwingend recht worden beschouwd.

* Bescherming van het belang van de vennootschap?

In de institutionele opvatting wordt aan de vennootschap een eigen belang toegekend, namelijk het belang bij het eigen gezonde voortbestaan. In die opvatting heeft

78 Zie onder meer Asser/Maeijer/Van Solinge \& Nieuwe Weme 2-II^ 2009, nr. 395.

79 Zie Timmerman I99I, p. 7 en Meinema 2003, p. 27-3I.

8o Zie bijvoorbeeld Meinema 2003, die stelt dat de machtenscheiding zodanig dient te zijn dat tussen de organen een machtsevenwicht bestaat. In joint venture-vennootschappen is daarvan in de regel geen sprake en vindt men van de klassieke dualistische structuur weinig tot niets terug, zoals Den Boogert terecht aangeeft (AA I995, p. 73).

8I Zie ook D.F.M.M. Zaman en I.C.P. Groenland, 'Tussen contract en instituut: waar zweeft de FlexBV?', TvOB 2009, 6, p. I69.

82 Aldus ook Den Boogert, AA I995, p. 73, die stelt dat men in joint venture-vennootschappen van de klassieke dualistische structuur weinig tot niets terugvindt. L. Timmerman, 'Een BV zonder bestuur en zonder aandeelhoudersvergadering', Ondernemingsrecht 2004/9, stelt zelfs dat een bv zonder bestuur 'niet bij voorbaat te verwerpen dan wel onjuist of onuitvoerbaar' is.

83 Blanco Fernández, WPNR 2005, p. 518. 
dwingend recht ook de functie dit belang van de vennootschap te beschermen. ${ }^{84}$ In de contractuele visie lost dit belang op in de belangen van alle bij de vennootschap betrokkenen. In ieder geval voor de persoonsgebonden vennootschap, waarin het aandeelhoudersbelang voorop staat, achten wij de contractuele visie een meer passend uitgangspunt. Wij zullen bescherming van het belang van de vennootschap in het navolgende dan ook niet als een functie van dwingend recht beschouwen..$^{85}$

Ten slotte noemen wij hier nog een vaak in verband met stemovereenkomsten genoemde nietigheidsgrond. Volgens de heersende opvatting is een stemovereenkomst nietig indien haar doel is bepaalde wettelijke of statutaire voorschriften 'bij voortduring te frustreren'. ${ }^{86}$ Wij gaan ervan uit dat deze 'regel' niet van toepassing is als het gaat om statutaire regels die de gezamenlijke aandeelhouders in een latere overeenkomst hebben willen wijzigen. De latere wilsovereenstemming van de gezamenlijke aandeelhouders heeft immers niet tot doel hun in de statuten vastgelegde afspraken te frustreren maar hen te wijzigen. ${ }^{87}$

\subsection{Buitenstatutaire regelingen en de openbaarheidsfunctie van dwingend vennootschapsrecht}

Beschrijuing van de problematiek

Keren wij nu terug naar de openbaarheidsfunctie van dwingend vennootschapsrecht, die zoals gezegd in de heersende opvatting ziet op twee gebieden van het vennootschapsrecht: de wettelijke bevoegdheidsverdeling en de duurzame structuur van de vennootschap. De openbaarheidsfunctie brengt met zich dat waar de wet afwijking of aanvulling van een wettelijke regel toestaat, deze afwijkende of aanvullende regeling in beginsel in de (openbaar gemaakte) statuten dient te worden neergelegd. Maar wat is de reikwijdte van de openbaarheidsfunctie?

De discussie is diffuus en wordt vertroebeld door een aantal factoren. Ten eerste is een aantal schrijvers van mening dat de openbaarheidsfunctie op de gehele interne inrichting van de vennootschap ziet; dit zou betekenen dat er dan geen enkele

84 Maeijer, passim; zie recentelijk ook A.F. Verdam, 'Het vennootschappelijk belang: méér dan "enlightened shareholder value", Ondernemingsrecht 2013-3, p. 93-IOI. Vgl. (zonder stellingname) Meinema 2003, p. I8.

85 Timmerman I99I noemt verder nog als grond voor c.q. functie van dwingend recht de 'doelmatige inrichting van de vennootschap' en de zogenoemde Institutionenschutz, dat wil zeggen de handhaving van de eigen kenmerken die de wetgever aan de vennootschap heeft willen geven. Elders noemt Timmerman de 'doorwerking van grondrechten' (recht op gelijke behandeling, recht op bescherming van eigendom) als grond voor dwingend recht (Timmerman 2005, p. 6-7). Deze functies blijven hier verder buiten beschouwing. Meinema 2003, p. I6-I9, noemt nog het belang van toekomstige aandeelhouders, ook wel genoemd Kapitalmarktschütz. Bij de persoonsgebonden vennootschap speelt dit geen rol omdat toetreding als aandeelhouder zoals gezegd gepaard gaat met toetreding tot de aandeelhoudersovereenkomst.

86 Asser/Maeijer/Van Solinge \& Nieuwe Weme 2-II^ 2009, nr. 386; Dortmond 2013, nr. 2I7.I.

87 Dortmond 20I3, nr. 2I7.I, geeft als voorbeeld van een ongeoorloofde contractuele regeling 'een stemovereenkomst die tot strekking heeft, dat voor besluiten die volgens de statuten bij volstrekte meerderheid kunnen worden genomen, in feite voortdurend een versterkte meerderheid nodig is'. Maar die situatie was nu net een van de gevallen waarbij deze vorm van doorwerking in rechte werd gehonoreerd (VenV). Zie hierover verder paragraaf 3 . 
buitenstatutaire regeling op dit vlak meer kan bestaan. ${ }^{88}$ Ten tweede is niet duidelijk voor welke derden welke onderdelen van de interne inrichting openbaar dienen te zijn en welk belang deze derden bij openbaarheid daarvan hebben. Voorts begint een groot aantal wettelijke voorschriften in Boek 2 met de tournure 'De statuten kunnen bepalen' of 'In de statuten kan worden bepaald'. ${ }^{89}$ De vraag die hierbij rijst is of dat betekent dat een buitenstatutaire regeling geldigheid mist. ${ }^{\circ}$ Ten slotte bepaalt de wet met betrekking tot een aantal onderwerpen dat zij bij of krachtens de statuten kunnen worden getroffen. Dat betekent dat de statuten kunnen aangeven dat de regeling in een ander document is neergelegd. Volgens de heersende opvatting dient de regeling dan in een besluit van een vennootschapsorgaan of in een (door een vennootschapsorgaan bij besluit vastgesteld) reglement te worden neergelegd. ${ }^{9 \mathrm{I}}$ De vraag die daarbij rijst, is of de regeling ook in een overeenkomst kan worden neergelegd.

Over deze materie is in het bijzonder in de periode 1995-2004 veel discussie geweest, welke discussie wel bekend staat onder de benaming 'bij of krachtens de statuten'. Voor een goed begrip van de materie is een korte samenvatting van de discussie noodzakelijk. Het is daarbij van belang voor ogen te houden dat de discussie zich bijna geheel toespitste op beurs-nv's. De discussie ging oorspronkelijk over de vraag of, als de wet bepaalt dat een bepaalde regeling (het ging daarbij specifiek om een winstverdelingsregeling ${ }^{92}$ 'bij de statuten', dat wil zeggen in de statuten, kon worden getroffen, de statuten dan ook konden bepalen dat die regeling door de algemene vergadering kon worden getroffen. Van Solinge sr., zich deels baserend op Van der Grinten en gesteund door Lijdsman, vond dat dit kon en alle anderen vonden

88 De gebezigde terminologie is ook niet altijd behulpzaam. Zo wordt wel van 'openbare inrichting' en 'openbare bevoegdheidsverdeling' gesproken, maar het gaat nu juist om die regels die vanwege de openbaarheidsfunctie van dwingend recht in de statuten moeten worden opgenomen. Daarnaast spreekt men ook wel van regels inzake de wettelijke en statutaire bevoegdheidsverdeling, maar het gaat juist om de vraag of een regel inzake de bevoegdheidsverdeling in de statuten moet worden opgenomen.

89 Deze formulering stamt deels uit de departementale richtlijnen voor ambtenaren van het ministerie van Justitie, die tot 200 I goedkeuring moesten verlenen aan door de notaris ingezonden conceptstatuten. Zonder die goedkeuring kon de notaris de oprichtingsakte of akte van statutenwijziging niet passeren.

90 Zoals hierboven aangegeven zijn contractuele afwijkingen van regelend vennootschapsrecht in ieder geval rechtsgeldig, ook al bevat de wettelijke bepaling in kwestie de tournure 'de statuten kunnen bepalen', maar in deze paragraaf gaat het om een andere categorie, namelijk om regelingen inzake de duurzame structuur en de bevoegdheidsverdeling ten aanzien waarvan (de openbaarheidsfunctie van) dwingend recht met zich zou brengen dat zij alleen in de statuten kunnen worden neergelegd.

9I Ten Berg, preadvies 2002, p. I89, beargumenteert dat kort gezegd als volgt: par. 9 van de richtlijnen gaf aan dat krachtens betekent: door een orgaan; de wetgever heeft de bepaling in de wet overgenomen ter vervanging van par. 9 en niet aangegeven dat iets anders wordt bedoeld dan in de richtlijnen. Wij achten dit geen overtuigende argumentatie en merken op dat de passage uit de parlementaire geschiedenis waarnaar Ten Berg verwijst (Kamerstukken II I998/99, 26 277, nr. 3, p. II) niet handelt over deze kwestie.

92 Art. 2:I05 lid I BW voor nv's bepaalt dat de winst aan de aandeelhouders toekomt tenzij 'bij de statuten' anders is bepaald. Art. 2:2I6 lid I BW bepaalde hetzelfde tot I oktober 2013 en bepaalt sindsdien dat de algemene vergadering bevoegd is tot winstbestemming. 
dat dit (waarschijnlijk) niet kon. ${ }^{93}$ De anderen beriepen zich daarbij in het bijzonder op het volgende argument: als een statutaire grondslag zoals door Van Solinge sr. genoemd, was toegestaan, zouden de woorden 'bij of krachtens' zijn gebruikt (zie over deze redenering verder hieronder).

Verder beriepen de meeste auteurs zich in de een of andere vorm op het openbaarheidsvereiste: de statuten regelen de interne verhoudingen, de inrichting van de vennootschap, en die moet immers kenbaar zijn voor aandeelhouders, bestuurders, commissarissen, de ondernemingsraad en crediteuren. ${ }^{94}$ Aan het andere eind van het spectrum staat Van Schilfgaarde, die zich heeft afgevraagd of de openbaarheid van inrichting in zijn algemeenheid wel een fundamenteel beginsel is. ${ }^{95}$

Ten slotte is zoals gezegd niet duidelijk wat precies voor wie kenbaar moet zijn (men spreekt in het algemeen over 'regels die in de statuten thuishoren') en welk specifiek belang de betrokkene bij de kenbaarheid heeft. Buijn meent dat betrokkenen moeten kunnen kennisnemen van de statutaire inrichting 'en aan de hand van het beeld dat die inrichting geeft, besluiten of, en zo ja op welke wijze, zij zullen omgaan met de vennootschap. ${ }^{96}$ Het komt ons niet aannemelijk voor dat derden hun besluit om met een vennootschap in zee te gaan, zullen laten afhangen van haar interne structuur (behalve bij een voorgenomen minderheidsparticipatie).

Een laatste problematische kwestie is de volgende. Buitenstatutaire documenten behoeven niet openbaar gemaakt te worden. Bij regelingen inzake de wettelijke bevoegdheidsverdeling en de duurzame structuur waarvan de wet aangeeft dat deze krachtens de statuten mogen worden getroffen, doet zich een paradox voor: de openbaarheidsfunctie ziet dan nog slechts op een verwijzing in de statuten naar het buitenstatutaire document waarin de regeling is of wordt neergelegd; daarna is de openbaarheidsfunctie uitgewerkt. ${ }^{97,}{ }^{98}$ Het maakt voor de kenbaarheid van de regeling

93 Zie voor uitgebreide verwijzingen naar deze en andere bijdragen in de discussie Asser/Van Solinge \& Nieuwe Weme 2-IIa* 2013, nr. 206.

94 Buijn, daarin bijgevallen door Ten Berg, noemt nog een 'dogmatisch' bezwaar, namelijk dat met het verwijzen naar aandeelhoudersovereenkomsten afbreuk wordt gedaan aan de institutionele leer. Dat is een apriorisme en geen argument. Verder betoogt hij dat derden erop dienen te kunnen vertrouwen dat de interne verhoudingen binnen de vennootschap ook daadwerkelijk gelden zoals ze gepresenteerd worden. Tot slot noemt Ten Berg in navolging van Buijn als argument voor (integrale) opname van een regeling in de statuten dat de inhoud van de statuten alleen door statutenwijziging kan worden veranderd en wijziging van een buitenstatutair document langs andere (eenvoudiger) weg kan geschieden, terwijl de inhoud van dat document voor de uitvoering van de gehele regeling wel relevant is. Zie Ten Berg, preadvies 2002, p. I87 met literatuurverwijzingen. Ons is de kracht van dit argument niet duidelijk.

95 P. van Schilfgaarde in: Verslag van de discussie KNB-vergadering 2002 ('Statuten zonder bezwaar'), losse WPNR-bijlage 2002, p. 28; zie ook F.K. Buijn, 'KNB; Statuten zonder bezwaar', Ondernemingsrecht 2002, I5, p. 479.

96 Buijn I999, p. I20.

97 Aldus reeds Van Schilfgaarde in genoemd discussieverslag. Hij komt tot dit oordeel op grond van de volgende redenering: in een reglement kan alles staan wat de statuten en de wet niet verbieden voor wat betreft de inrichting, de taakverdeling, de besluitvorming; een reglement is niet-openbaar; wat houdt de openbaarheidsfunctie van inrichting en bevoegdheidsverdeling dan nog in? Hieronder zullen wij deze redenering volgen, zij dat dat wij niet zo gemakkelijk als Van Schilfgaarde over de 'bij of krachtens'-kwestie zullen stappen.

98 De minister merkte in dit verband terecht op: 'Vanwege de vennootschapsrechtelijke gevolgen is het van belang dat een regeling duidelijk kenbaar is. Een statutaire regeling voldoet aan de eisen van kenbaarheid. De inhoud van een regeling krachtens de statuten zal daarentegen minder of 
immers geen verschil meer of partijen de regeling in een besluit, een reglement of in een overeenkomst hebben neergelegd waarnaar in de statuten wordt verwezen. ${ }^{99}$

Benadering van de problematiek

Laten we beginnen met de 'bij of krachtens'-discussie. Lijdsman heeft terecht erop gewezen dat de wetgever op vele plaatsen de woorden 'bij/in/krachtens/bij of krachtens de statuten' gebruikt zonder dat daaraan een eenduidig systeem ten grondslag ligt, en dat per bepaling moet worden bekeken of een regeling (in haar geheel) in de statuten moet worden vastgelegd. ${ }^{100}$ Betreft het een regeling inzake de duurzame structuur van de vennootschap ten aanzien waarvan de openbaarheidsfunctie een regeling in de statuten vereist, dan is een contractuele regeling niet mogelijk. Een duidelijk voorbeeld hiervan is de instelling van een raad van commissarissen. Wij menen dat derden in beginsel niets met de interne structuur van de vennootschap te maken hebben en dat de openbaarheidsfunctie van dwingend recht (zeer) beperkt moet worden opgevat. Behoort een regeling niet tot deze categorie, dan kan onzes inziens een contractuele regeling worden getroffen, waarbij een statutaire grondslag voldoende is. Men kan zich zelfs afvragen of deze grondslag in alle gevallen vereist is. Zo twijfelt niemand aan de geldigheid van contractuele afspraken ten aanzien van de besluitvorming in de algemene vergadering (quorum en versterkte meerderheden) zonder statutaire grondslag, dat wil zeggen zonder dat de statuten aangeven dat in een ander document bepaalde meerderheids- en quorumregels zijn afgesproken. Dergelijke contractuele regelingen zijn naar algemeen wordt aangenomen geldig ondanks het feit dat de wet bepaalt dat besluiten met gewone meerderheid en zonder quorum worden genomen tenzij bij de statuten anders is bepaald (artikel 2:230 lid I respectievelijk lid $2 \mathrm{BW}$ ).

Als een regeling in een reglement of besluit wordt neergelegd, krijgt zij een zekere vennootschappelijke werking, dat wil zeggen dat zij van rechtswege geldt voor de bij de vennootschap betrokkenen en dat besluiten genomen in strijd met de in het reglement vervatte regeling, vernietigbaar zijn. De door de wet aangegeven mogelijkheid om een regeling bij of krachtens de statuten vast te leggen zegt onzes inziens in beginsel niets over de rechtsgeldigheid of de afdwingbaarheid van een

geheel niet kenbaar zijn.' Kamerstukken II 2006/07, 3I 058, nr. 3, p. I5-I7. Op een andere plaats betoogt de minister daarentegen dat de onderwerpen die krachtens de statuten in een reglement kunnen worden geregeld uitsluitend interne aangelegenheden mogen betreffen die niet voor derden kenbaar hoeven te zijn (Kamerstukken II 2009/1o, 32 426, nr. 3, p. 2). Het is ons niet duidelijk hoe zich dit standpunt verhoudt tot de openbaarheidsfunctie van dwingend recht.

99 Zie ook Van Schilfgaarde in zijn heldere bespreking van het preadvies Statuten zonder bezwaar: als een aandeelhoudersovereenkomst vennootschappelijke werking heeft 'en daarmee doordringt tot de inrichting van de vennootschap', waarom is dan niet voldoende dat de kenbaarheid of traceerbaarheid daarvan als voorwaarde voor die vennootschappelijke werking wordt gesteld?' (P. van Schilgaarde, Bespreking van 'Statuten zonder bezwaar', WPNR 2002/6503, p. 64I). Vgl. W. Westbroek en A.A. Schulting in: C.A. Boukema e.a. (red.), Rechtspersonen, Commentaar Departementale Richtlijnen 1986, Deventer: Kluwer (losbl.), aant. 4 bij paragraaf 9, die kennelijk van oordeel zijn dat als de statuten wel in de mogelijkheid van bevoegdheidsbeperkingen voorzien, deze ook in een overeenkomst kunnen worden neergelegd.

Lijdsman, De NV (I997), p. 234. 
contractuele regeling van dezelfde strekking. Een contractuele regeling is, zoals in de vorige paragraaf betoogd, slechts ongeldig als zij ziet op de wettelijke bevoegdheidsverdeling en de duurzame structuur van de vennootschap terwijl afwijking van de wettelijke regeling vanwege de openbaarheidsfunctie van dwingend vennootschapsrecht uitsluitend in de statuten mag worden gegeven. ${ }^{\text {Ior }}$ Betreft het niet een van deze gevallen, dan zouden wij willen aannemen dat de regeling ook in een buitenstatutair document (reglement of overeenkomst) kan worden neergelegd. Een contractuele regeling op dit vlak is naar onze mening in beginsel geldig en jegens de medeaandeelhouders en de vennootschap afdwingbaar.

Er dient dus per geval te worden bekeken of met betrekking tot een specifieke wettelijke bepaling de openbaarheidsfunctie met zich brengt dat een regeling uitsluitend in de statuten kan worden opgenomen. Hieronder passeren enkele gevallen de revue. ${ }^{\text {102 }}$ Het instellen van een raad van commissarissen in de zin der wet is het meest evidente voorbeeld: dit dient in de statuten te geschieden en kan niet in een reglement of aandeelhoudersovereenkomst. ${ }^{103}$ Een ander voorbeeld is onzes inziens delegatie van emissiebevoegdheid. Hier is sprake van een iets andere techniek dan de 'bij-of-krachtens'-techniek: deze bevoegdheid kan volgens artikel 2:206 BW alleen in de statuten of bij besluit van de algemene vergadering worden gedelegeerd. Deze techniek wordt ook gebruikt bij het vergaderrecht: in de statuten of bij besluit van de algemene vergadering kan vergaderrecht worden toegekend (artikel 2:227 BW). Delegatie van emissiebevoegdheid en toekenning van vergaderrecht kan dus niet in een reglement of bij overeenkomst geschieden. De regel dat bestuursbesluiten aan de goedkeuring van een ander orgaan kunnen worden onderworpen is, zouden wij menen, een belangrijke regeling inzake de wettelijke bevoegdheidsverdeling, en lijkt bij uitstek een regeling die in de statuten zou moeten worden opgenomen. Maar de wet geeft aan dat de goedkeuringsbevoegdheid ook krachtens de statuten, dus in een niet-openbaar document kan worden verleend. ${ }^{\text {104 }}$ Een ander voorbeeld op het gebied van de bevoegdheidsverdeling is die tussen executives en non-executives in een one-tier board. Deze bevoegdheidsverdeling kan geheel buitenstatutair geschieden; voldoende is dat de one-tier board in de statuten is 'ingesteld' (artikel 2:239a BW). ${ }^{\text {105 }}$ Een reeds eerder genoemd punt betreft het creëren van van de wettelijke default-regels

IoI Of als de regeling (waar dan ook neergelegd) in strijd is met een andere dwingendrechtelijke regel zoals opgesomd in paragraaf 2.4 .

I02 Een systematische analyse van alle wettelijke regels inzake de bevoegdheidsverdeling en de duurzame structuur van de vennootschap - en van de vraag of zij (al dan niet in hun geheel) in de statuten dienen te worden vastgelegd - is gewenst maar valt buiten het bestek van dit preadvies.

I03 Wij laten hier rusten de mogelijkheid van contractuele structurering van toezicht, zie hierover onder meer Van Schilfgaarde I99I, p. II-I8.

I04 Ten Berg, preadvies 2002, p. I88, schrijft over deze mogelijkheid: 'Het argument van de kenbaarheid voor derden lijkt hier minder manifest nu het gaat om een beperking van de interne bestuursbevoegdheid.' Uiteraard regardeert genoemde beperking niet derden die met de vennootschap handelen, maar dat geldt (behoudens vertegenwoordiging bij bestuursbesluit) toch voor alle regels inzake de interne inrichting?

I05 Vgl. de instelling van een raad van commissarissen, die zoals betoogd ook in de statuten dient te geschieden. 
afwijkende besluitvormingsregels (quorum en versterkte meerderheden). ${ }^{106}$ De wet bepaalt dat dergelijke afwijkende regels 'bij de statuten' dienen te worden gegeven, maar de heersende opvatting is dat deze - met een statutaire grondslag - ook in een reglement kunnen worden opgenomen ${ }^{107}$ en - zonder statutaire grondslag - in een overeenkomst. In een overeenkomst opgenomen regelingen inzake quorum en meerderheden ontberen weliswaar de vennootschappelijke werking van een reglement in die zin dat een besluit genomen in strijd met in een reglement vervatte besluitvormingsregels vernietigbaar is op grond van artikel 2:I5 lid I, onder c, BW), maar in de volgende paragraaf zullen we zien dat de rechter een soortgelijke doorwerking heeft erkend.

\section{Doorwerking van aandeelhoudersovereenkomsten}

In deze paragraaf zal de doorwerking van verschillende soorten afspraken tussen aandeelhouders aan de orde komen. Eerst wordt de doorwerking van overeenkomsten tot aanbieding en afname van aandelen behandeld en daarna de doorwerking van stemovereenkomsten.

\section{A Doorwerking van overeenkomsten tot aanbieding en afname van aandelen}

Alvorens wij ingaan op de doorwerking van contractuele regelingen omtrent de aanbieding en afname van aandelen in een bv eerst een opmerking over statutaire regelingen op dit vlak. Het opnemen van een bepaalde regeling in de statuten betekent dat deze regeling per definitie openbaar wordt. De statuten moeten immers worden neergelegd ten kantore van het handelsregister. Het nieuwe bv-recht brengt hierin geen verandering. In de memorie van toelichting overweegt de minister dat de statuten zijn bedoeld voor afspraken die ook voor derden betekenis hebben en daarom voor hen kenbaar dienen te zijn. ${ }^{108}$ Lang niet alles wat in de statuten staat geregeld is echter voor derden van belang. Voor verbintenissen tussen de vennootschap en haar aandeelhouders en tussen aandeelhouders onderling zal in het algemeen gelden dat de belangen van derden daarbij niet zijn betrokken. Maakt het voor de geldigheid en afdwingbaarheid van dit soort verbintenissen uit of de deze in de statuten dan wel in de overeenkomst zijn vastgelegd? En wat is rechtens indien sprake is van discrepantie tussen beide regelingen? Aangezien er sinds de inwerkingtreding van de Wet

Io6 Deze besluitvormingsregels behoren onzes inziens overigens niet tot categorie wettelijke bevoegdheidsverdeling en duurzame structuur.

I07 Zie Asser/Maeijer/Van Solinge \& Nieuwe Weme 2-II^ 2009, nr. 420 (inzake een bestuursreglement). Hetzelfde geldt voor een bepaling inzake meervoudig stemrecht van bestuurders en commissarissen. Anders: J.D.N. Schoonbrood, 'De in de wet overgenomen bepalingen van de Departementale Richtlijnen I986', in: Bosse e.a. (red.), Preadvies KNB 2002, p. Ioo.

Io8 Kamerstukken II 2006/07, 3I 058, nr. 3, p. 3-4 (MvT). 
vereenvoudiging en flexibilisering bv-recht veel is veranderd zal bij de beantwoording van deze vragen steeds ook aandacht worden besteed aan het oude bv-recht.

\section{I Blokkeringsregelingen}

Vanaf het ontstaan van de Nederlandse bv in I97I schreef de wetgever dwingendrechtelijk voor dat de aandelen in de bv niet vrij overdraagbaar mochten zijn. De statuten van een bv moesten een blokkeringsregeling ${ }^{\mathrm{I09}}$ bevatten. Deze blokkeringsregeling mocht echter ook weer niet tot gevolg hebben dat de overdracht van aandelen onmogelijk of uiterst bezwaarlijk werd. ${ }^{\text {Io }}$ De wet voorzag voorts in de waarborg dat de overdragende aandeelhouder recht had op een koopprijs die gelijk was aan de waarde van de over te dragen aandelen, vastgesteld door een of meer onafhankelijke deskundigen. ${ }^{\text {II }}$ Bovendien sprak de wettekst over 'contante betaling' van de koopprijs, ${ }^{\mathrm{II} 2}$ waaruit volgde dat geen betalingsregeling in de statuten mocht worden opgenomen. Onder het oude recht is in de loop der tijd uitgebreid gediscussieerd over de mogelijkheden om in een aandeelhoudersovereenkomst af te zien van bepaalde bevoegdheden die uit de dwingendrechtelijk voorgeschreven blokkeringsregeling voortvloeiden. Zo vroeg Ten Berg zich af of aandeelhouders contractueel afstand kunnen doen van de rechten die voortvloeien uit een in de statuten opgenomen aanbiedingsregeling. ${ }^{113}$ Het antwoord was naar zijn mening dat een algemene en onbeperkte afstand bij voorbaat door een aandeelhouder van zijn rechten uit een aanbiedingsregeling ongeldig was. Voor een beperkte afstand van rechten bij voorbaat zag hij wel mogelijkheden. De kern van de discussie was de vraag of de contractuele disposities niet te zeer streden met het karakter van de destijds dwingendrechtelijk voorgeschreven blokkeringsregelingen die het besloten karakter van de bv moesten waarborgen. De Kluiver en Meinema ${ }^{114}$ wezen er in dit verband terecht op dat de term 'afstand van recht' in de zin dat het recht of de bevoegdheid door de afstand tenietgaat, in wezen niet juist weergeeft waar het in deze overeenkomsten om draait. Het gaat om het afzien van de uitoefening van bevoegdheden. Het verschil is wezenlijk: het contractueel afzien van de uitoefening van een bepaalde bevoegdheid leidt niet tot het tenietgaan van diezelfde bevoegdheid.

Sinds de inwerkingtreding van de Wet vereenvoudiging en flexibilisering bv-recht is het niet langer dwingendrechtelijk voorgeschreven om in de statuten van een bv de overdraagbaarheid van aandelen te beperken. De aandeelhouders van een persoonsgebonden bv zullen er desondanks voor kiezen om de overdraagbaarheid van de

Io9 Ingevolge art. 2:I95 BW (oud) waren er twee varianten: de goedkeuringsregeling waarbij een orgaan van de vennootschap de bevoegdheid tot het goedkeuren van een voorgenomen aandelenoverdracht werd toebedeeld (lid 4) en een aanbiedingsregeling waarbij werd voorgeschreven dat de aandeelhouder die een of meer aandelen wilde vervreemden deze eerst moest aanbieden aan zijn medeaandeelhouders (lid 5).

IIo Art. 2:195 lid 8 BW (oud).

III Art. 2:195 lid 4 BW (oud).

II2 Art. 2:I95 lid 4 en 5 BW (oud).

II3 Ten Berg, preadvies (2002), p. I9I-I92.

II4 De Kluiver en Meinema, WPNR 2002, 6503, p. 65I-653. 
aandelen te beperken. Deze vennootschap wordt immers intuitu personae aangegaan en haar aandeelhouders zijn in beginsel niet vervangbaar. Volgens de heersende leer is de levering van aandelen in strijd met een statutaire blokkeringsregeling ongeldig. Het nieuwe bv-recht heeft hierin geen wijziging gebracht. Het effect van een statutaire blokkeringsregeling is zo sterk dat de overdracht in strijd daarmee niet tot stand komt. Men spreekt van de goederenrechtelijke werking die uitgaat van de statutaire blokkering van de overdracht van aandelen. Contractuele regelingen omtrent blokkering van aandelen ontberen dit effect: overdracht van aandelen in strijd met een contractuele blokkeringsregeling levert wanprestatie op maar de overdracht is op zichzelf wel geldig. Hoe kan deze goederenrechtelijke werking dogmatisch worden verklaard? De heersende opvatting is thans dat een statutaire beperking de overdraagbaarheid van het aandeel in de zin van artikel 3:83 lid 3 BW beperkt. Deze beperking betreft een vermogensrechtelijk kenmerk van het aandeel zelf. ${ }^{\text {II }}$ De beschikkings(on)bevoegdheid van de vervreemder staat hier verder buiten. Wij kunnen ons in deze opvatting - mede in het licht van het nieuwe bv-recht ${ }^{116}$ - goed vinden.

$\mathrm{Nu}$ de beslotenheid van de bv niet langer wettelijk verplicht is, is het interessant om te bezien of contractuele afwijkingen van statutaire regelingen omtrent blokkering van aandelen naar huidig recht geldig en afdwingbaar zijn. Stel het geval dat voor (vrijwillige) overdracht van aandelen statutair is voorgeschreven dat de aandeelhouder zijn aandelen eerst moet aanbieden aan zijn medeaandeelhouders terwijl de aandeelhouders zich tevens contractueel hebben verbonden om bij overdracht van aandelen een goedkeuringsregeling na te leven. Er is dus sprake van een discrepantie tussen de statutaire regeling en de contractuele regeling. Onzes inziens dienen in een dergelijk geval beide regelingen te worden nageleefd.

Pregnant is de vraag wat rechtens is indien partijen in de statuten hebben gekozen voor een aanbiedingsregeling maar zich in een latere overeenkomst hebben verbonden om voor de toekomst af te zien van de uitoefening van hun reflectierechten die uit deze statutaire bepalingen voortvloeien. Is deze contractuele regeling geldig en afdwingbaar? Er kunnen goede redenen zijn waarom aandeelhouders op een bepaald moment besluiten hun samenwerking te beëindigen en ondanks het bestaan van een statutaire aanbiedingsregeling vrije overdracht van aandelen toe te staan. De aandeelhouder die tot aanbieding aan zijn medeaandeelhouders verplicht is, kan door de laatstgenoemden van deze verplichting worden ontheven bij obligatoire overeenkomst. Dit kan doordat de medeaandeelhouders afzien van de uitoefening van hun reflectierechten. Het gevolg van een en ander is onzes inziens dat de statutaire aanbiedingsregeling buiten werking wordt gesteld zodat overdracht van de aandelen kan plaatsvinden zonder dat eerst tot aanbieding van de aandelen over behoeft te worden gegaan. Aangezien in een dergelijk geval geen sprake is van een overdracht in strijd met de statutaire regeling, speelt de goederenrechtelijke

II5 Asser/Van Solinge \& Nieuwe Weme 2-IIa` 20I3, nr. 404, p. 450.

II6 Zie bijvoorbeeld art. 2:I95 lid 4 BW dat spreekt over het 'beperken van de overdraagbaarheid van aandelen bij de statuten' en de 'ongeldigheid van een overdracht' die plaatsvindt in strijd met een dergelijke statutaire beperking. 
werking van de statutaire blokkeringsregeling verder geen rol. Het is immers (evenals onder het oude recht) ook mogelijk in de statutaire regeling zelf op te nemen dat de aandeelhouder zijn aandelen niet behoeft aan te bieden indien de medeaandeelhouders schriftelijk hebben verklaard af te zien van hun reflectierechten, waarna een vrije overdracht rechtsgeldig kan geschieden. Onzes inziens kan in persoonsgebonden verhoudingen een dergelijk afzien van rechten uit de overeengekomen statutaire blokkeringsregeling dan ook - met gelijke geldigheid - plaatsvinden in een latere overeenkomst. ${ }^{\text {II }}$

\subsection{Gedwongen aanbieding van aandelen}

Volgens het nieuwe artikel 2:I92 lid I onder c BW kunnen de statuten met betrekking tot alle aandelen of aandelen van een bepaalde soort of aanduiding bepalen dat een aandeelhouder in bepaalde gevallen gehouden is zijn aandelen of een deel daarvan aan te bieden en over te dragen. Het gaat dus om gedwongen aanbieding en overdacht van aandelen. Ook het oude recht ${ }^{118}$ bood deze mogelijkheid al. In de praktijk veel voorkomende statutaire clausules waren de verplichtingen tot aanbieding ingeval niet langer werd voldaan aan de statutaire vereisten voor het aandeelhouderschap, in geval van faillissement of de surseance van betaling van een aandeelhouder of in geval van overlijden van een aandeelhouder. Een van de twistpunten onder het oude recht was de vraag in welke gevallen een aanbiedings- en overdrachtplicht kon ontstaan, meer specifiek de vraag naar de geldigheid van een statutaire bepaling inhoudende dat een aandeelhouder bij besluit tot aanbieding en overdracht van zijn aandelen verplicht kon worden. ${ }^{\text {I9 }}$ De tegenstanders van een dergelijke statutaire clausule wezen op een opmerking in de memorie van toelichting bij het inmiddels vervallen artikel 2:I95a BW waarin de bepaling als onredelijk wordt gekenschetst. ${ }^{\mathrm{I} 20}$ De voorstanders waren van mening dat het in persoonsgebonden verhoudingen heel goed denkbaar is en ook heel redelijk kan zijn om aanbiedings- en overdrachtverplichtingen van eigen vinding te creëren. ${ }^{\mathrm{II}}$

Onder het nieuwe bv-recht zouden wij menen dat niet alleen in aandeelhoudersovereenkomsten maar ook in statuten vrijelijk bepalingen kunnen worden opgenomen inhoudende dat aandeelhouders hun aandelen tegen een bepaalde prijs aan andere aandeelhouders of derden moeten aanbieden en overdragen. Een mooi voorbeeld hiervan is een drag along-bepaling. Een dergelijke bepaling geeft de meerderheidsaandeelhouders het recht om bij een hun welgevallig overnamebod de minderheidsaandeelhouder te verplichten om zijn aandelen aan te bieden en over te dragen aan degene die het overnamebod doet. Het beoogde eindresultaat is dat de verkopende

II7 Dortmond 20I3, nr. I8I.4, gaat ervan uit dat aandeelhouders niet in het algemeen afstand kunnen doen van hun reflectierechten; het geheel opheffen van de beslotenheid kan alleen bij statutenwijziging plaatsvinden.

II8 Art. 2:195 a BW (oud).

II9 Schoonbrood in: Bosse e.a., KNB Preadvies 2002, p. 77.

I20 Kamerstukken II I998/99, 26277 nr. 3, p. 8.

I2I Van Schilfgaarde 2002, p. 644-645. 
meerderheidsaandeelhouder kan bewerkstelligen dat alle geplaatste aandelen aan de door hem geselecteerde overnemer worden overgedragen hetgeen doorgaans bijdraagt aan het realiseren van een beter verkoopresultaat. ${ }^{\mathrm{I} 22}$ Staande praktijk is om drag along-bepalingen op te nemen in een aandeelhoudersovereenkomst waarbij alle aandeelhouders partij zijn. De mogelijkheid om een drag along-clausule statutair vorm te geven was onder het oude recht kwestieus maar onder het nieuwe artikel 2:I92 lid I onder c BW liggen de kaarten onzes inziens anders. De parlementaire geschiedenis houdt ons in dit verband voor dat de gevallen waarin de verplichting tot aanbieding en overdracht geldt 'objectief bepaalbaar' moeten zijn. Daaraan wordt direct toegevoegd dat het zal afhangen van de specifieke inhoud van de regeling of aan deze voorwaarde is voldaan. ${ }^{123}$ Het wordt uit de parlementaire geschiedenis niet duidelijk wat de term 'objectief bepaalbaar' precies inhoudt. Elders spreekt de minister over 'voldoende bepaalbaar'. ${ }^{124}$ Mede gezien het obligatoire karakter van deze regelingen zien wij niet in waarom op dit punt voor statutaire regelingen andere, kennelijk zwaardere, eisen zouden moeten gelden dan voor contractuele regelingen. ${ }^{25}$ Het nieuwe artikel 2:I92 lid 2 BW makt expliciet duidelijk dat het tijdstip van inwerkingtreding van een statutaire verplichting als bedoeld in artikel 2:I92 lid I onder c BW afhankelijk mag zijn een besluit van een daartoe in de statuten aangewezen orgaan van de vennootschap. Ook kunnen de statuten bepalen dat een daartoe in de statuten aangewezen vennootschapsorgaan ontheffing kan verlenen van een dergelijke statutaire verplichting.

Statutaire aanbiedings- en overdrachtsverplichtingen hebben noch onder het oude noch onder het nieuwe recht goederenrechtelijke werking. Er is dus in dit opzicht geen verschil met de werking van contractuele aanbiedings- en overdrachtsverplichtingen. Ook hier geldt weer dat zowel de statutaire als de contractuele regeling een obligatoire rechtsverhouding creëert tussen de aandeelhouders. De contractuele bepaling die is aangegaan door alle aandeelhouders en ten doel heeft om af te wijken van een eerder statutair vastgelegde aanbiedingsverplichting is naar onze mening geldig.

Zowel de statuten als aandeelhoudersovereenkomsten kunnen voorzien in sanctiebepalingen voor het geval de aanbiedingsverplichting niet wordt nageleefd. Een sterk instrument is de statutaire regeling inhoudende dat indien en zolang een aandeelhouder zijn aanbiedingsverplichting niet naleeft, zijn stemrecht, vergaderrecht en recht op uitkeringen worden opgeschort. ${ }^{126}$ Deze statutaire sancties kunnen

I22 Een drag along wordt in praktijk dikwijls gecombineerd met een tag along-bepaling inhoudende het recht van een minderheidsaandeelhouder om van een verkopende meerderheidsaandeelhouder te verlangen dat, in het geval die meerderheidsaandeelhouders zijn aandelen aan een derde wenst te verkopen, hij tevens de aandelen van de minderheidsaandeelhouder in de verkooponderhandelingen moet betrekken zodat zowel de aandelen van de verkopende meerderheidsaandeelhouder als de aandelen van de minderheidsaandeelhouder worden verkocht tegen dezelfde prijs en condities.

I23 Kamerstukken II 2008/09, 3 I 058, nr. 6, p. I3.

I24 Kamerstukken II 2006/07, 3 I 058, nr. 3, p. 44.

I25 Art. 6: 227 BW schrijft overigens voor dat verbintenissen 'bepaalbaar' moeten zijn.

I26 Art. 2:I92 lid 4 BW. 
echter ook worden verbonden aan de niet-naleving van contractuele aanbiedingsverplichtingen. ${ }^{127}$ Onze conclusie is dat contractuele aanbiedings- en overdrachtsverplichtingen zowel ten aanzien van de inhoudelijke regeling als ten aanzien van de sanctiebepalingen in beginsel kunnen doorwerken binnen de rechtssfeer van de vennootschap. In die zin maakt het voor de rechtsgeldigheid en afdwingbaarheid van de regeling geen verschil of gekozen wordt voor contractuele dan wel statutaire clausules.

\subsection{Verbintenissen van aandeelhouders (artikel 2:I92 BW)}

Het oude recht begrensde de mogelijkheden om extra verplichtingen aan aandeelhouders op te leggen in artikel 2:I92 BW (oud) als volgt: 'Aan een aandeelhouder kan niet, zelfs niet door wijziging van de statuten, tegen zijn wil enige verplichting boven de storting tot het nominale bedrag van het aandeel worden opgelegd.'

In de literatuur bestond discussie over de uitleg van deze bepaling. De wetgever had de tekst in 1928 geïntroduceerd met het oog op verplichtingen van aandeelhouders jegens de vennootschap tot het leveren van producten of verrichten van diensten. ${ }^{128}$

Deze discussies kunnen wij thans achter ons laten want volgens het nieuwe artikel 2:192 lid I onder a BW kunnen de statuten bepalen dat 'verplichtingen van verbintenisrechtelijke aard' jegens de vennootschap of tussen aandeelhouders onderling aan het aandeelhouderschap zijn verbonden. Met de nieuwe term 'verplichtingen van verbintenisrechtelijke aard' wordt aangegeven dat statutaire verbintenissen ook verbintenissen kunnen omvatten waarvan onder de oude wet werd aangenomen dat deze uitsluitend in contractuele regelingen konden worden vastgelegd. Statutaire verbintenissen zullen in de praktijk meestal worden voorzien van flankerende sanctiebepalingen.

In de parlementaire geschiedenis maakt de minister er melding van dat een statutaire verbintenis tussen aandeelhouders een vennootschapsrechtelijk karakter heeft en moet worden onderscheiden van een 'gewone' contractuele verbintenis. ${ }^{\mathrm{I} 29} \mathrm{Hij}$ adstrueert dat statutaire regelingen, anders dan een aandeelhoudersovereenkomst, ook gelden voor later toetredende aandeelhouders. Door toe te treden als aandeelhouder van de vennootschap verbindt de aandeelhouder zich immers tot de in de statuten neergelegde verplichtingen terwijl de aandeelhouder slechts aan een overeenkomst gebonden is indien de bepalingen daarvan door hem zijn aanvaard. In het algemeen moge dit betoog van de minister juist zijn, voor de persoonsgebonden bv heeft het weinig betekenis. Indien alle aandeelhouders zich tevoren of gelijktijdig met het verkrijgen van de aandelen hebben onderworpen aan de bepalingen van een

I27 Kamerstukken II 2008/09, 3I 058, nr. 6, p. I-2 en p. 20.

I28 Van der Heijden en Van der Grinten I992, nr. I72; er speelde onder meer de kwestie of de bepalingen ook kunnen zien op verplichtingen tussen aandeelhouders onderling of dat het uitsluitend moest gaan om verplichtingen tussen aandeelhouders enerzijds en de vennootschap anderzijds.

I29 Kamerstukken II 2006/07, 3I 058, nr. 3, p. I6. 
aandeelhoudersovereenkomst, lopen statuten en overeenkomst immers parallel. Voor hen is er geen verschil tussen het opnemen van verbintenissen in de statuten of in de overeenkomst.

\subsection{Afname van aandelen}

Wij zouden willen aannemen dat een aandeelhouder in een persoonsgebonden bv naar maatstaven van redelijkheid en billijkheid een uittreedmogelijkheid behoort te worden geboden. Als men redeneert vanuit de continuïteit van de onderneming zijn er maar beperkte mogelijkheden: de positie van de uittredende aandeelhouder wordt overgenomen door (I) één of meer van de overige aandeelhouders, (2) de vennootschap of (3) een derde. Meestal wordt gekozen voor opvolging van de uittreder door diens medeaandeelhouders die dan de verplichting op zich nemen om de aandelen van de uittreder te kopen en af te nemen, met dien verstande dat indien één of meer van hen niet aan deze afnameverplichting kan voldoen, de vennootschap verplicht is de resterende aandelen in te kopen, een en ander met inachtneming van de wettelijke inkoopregels.

Onder het oude recht was het omstreden of het mogelijk is om een dergelijke afnameplicht statutair vorm te geven ${ }^{130}$ en ook het nieuwe bv-recht kent, buiten de wettelijke geschillenregeling, geen expliciete wettelijke grondslag voor een dergelijke statutaire afnameverplichting. In artikel 2:I92 lid I onder c BW wordt slechts gesproken over de mogelijkheid van statutaire aanbiedings- en overdrachtsverplichtingen. Betekent dit nu dat onder het nieuwe bv-recht deze regelingen ongeldig zijn? Met De Kluiver ${ }^{13 \mathrm{I}}$ zijn wij van mening dat een statutaire afnameverplichting binnen het bereik valt van de statutaire verbintenissen van artikel 2:I92 lid I onder a BW. Ook hier geldt naar onze mening dat dergelijke regelingen voldoende bepaalbaar moeten zijn.

Het opnemen van contractuele of statutaire afnameverplichtingen leidt, net zoals het opnemen van contractuele of statutaire aanbiedingsverplichtingen, tot het ontstaan van een obligatoire rechtsverhouding tussen de aandeelhouders. Hetgeen wij hiervoor hebben betoogd over de mogelijkheden om bij een latere contractuele bepaling af te wijken van een eerdere statutaire regeling geldt te dezen evenzeer.

\subsection{Geschillenregeling: uittreden en uitstoten van aandeelhouders}

Het uitgangspunt bij geschillenregelingen in persoonsgebonden bv's is dat de beknelde aandeelhouder zijn aandelen tegen een faire prijs moet kunnen overdragen aan één of meer medeaandeelhouders of aan de vennootschap zelf. De wettelijke geschillenregeling sluit hierbij aan. Naar aanleiding van de invoering van het

I30 Zie G.J.C. Rensen, Extra-verplichtingen van leden en aandeelhouders (diss. Nijmegen) (Serie vanwege het Van der Heijden Instituut, deel 83), Deventer: Kluwer 2005, p. 242-246 en de aldaar aangehaalde literatuur.

I3I H.J. de Kluiver, 'Naar een statutaire geschillenregeling', in: G. van Solinge e.a. (red.), Geschillen in de vennootschap (Serie vanwege het Van der Heijden Instituut, deel I05), Deventer: Kluwer 2010, p. 26-28. 
nieuwe bv-recht is ook de wettelijke geschillenregeling op verschillende punten gewijzigd. De wetgever heeft in de gewijzigde regeling nadrukkelijk aan aandeelhouders de mogelijkheid geboden om 'eigen' statutaire of contractuele geschillenregelingen op te stellen. Mede vanwege het obligatoire karakter van dit soort regelingen is er voor wat betreft de rechtsgeldigheid en afdwingbaarheid geen verschil of vastlegging ervan in de statuten of in een overeenkomst plaatsvindt: zij werken op gelijke wijze door in de rechtssfeer van de vennootschap. Statutaire of contractuele afnameverplichtingen kunnen door de aandeelhouders worden ingezet bij het vormgeven van uittredingsregelingen en statutaire of contractuele aanbiedingsverplichtingen kunnen de basis zijn van uitstotingsregelingen. In beginsel kan daarbij van alle onderdelen van de wettelijke geschillenregeling worden afgeweken waardoor de wettelijke bepalingen het karakter hebben gekregen van een default-regeling. Zo bepaalt artikel 2:339 lid 2 en 3 BW dat indien tussen partijen op grond van de statuten of een overeenkomst bepalingen omtrent de vaststelling van de waarde van de aandelen gelden, de deskundigen hun waardering moeten opstellen met in achtneming van deze bepalingen. De rechter kan zelfs bepalen dat, indien sprake is van een voldoende duidelijke maatstaf voor de bepaling van de waarde van de aandelen, de benoeming van deskundigen geheel achterwege kan blijven. In dat geval zal de rechter aan de hand van de statutaire of contractuele bepalingen de prijs zelf vaststellen.

Bij het opstellen van deze clausules moet evenwel rekening gehouden worden met de randvoorwaarden die in de wettelijke geschillenregeling zijn opgenomen om te voorkomen dat aandeelhouders in een geschilsituatie bekneld raken. ${ }^{\mathrm{I} 2}$ Ingevolge artikel 2: 337 lid I BW mogen de statutaire of contractuele geschillenregelingen de overdracht van de aandelen niet 'onmogelijk of uiterst bezwaarlijk' maken. Voor zover zij dat wel doen, kan daarop geen beroep worden gedaan en geldt de wettelijke regeling onverkort. Bovendien houdt de rechter op grond van artikel 2:340 lid 3 BW geen rekening met statutaire of contractuele regelingen ter vaststelling van de waarde van de aandelen voor zover dit zou leiden tot een 'kennelijk onredelijke prijs'. Uit het gebruik van de woorden 'kennelijk onredelijk' - een uitwerking van de beperkende werking van de redelijkheid en billijkheid (artikelen 2:8 lid 2 en 6:2 lid 2 BW) - volgt dat de rechter zich terughoudend dient op te stellen bij een eventuele terzijdestelling van door de aandeelhouders ontworpen statutaire of contractuele regels. ${ }^{\mathrm{I} 3}$

\subsection{Doorwerking van contractuele prijsbepalingsafspraken}

Zoals gezegd dienden de statuten van een bv onder het oude recht steeds een blokkeringsregeling te bevatten. De wet schreef voor dat deze blokkeringsregeling zodanig

I32 Volgens de wettelijke regeling is daarvan sprake indien aandeelhouders door hun gedragingen het belang van de vennootschap zodanig schaden dat het voortduren van hun aandeelhouderschap in redelijkheid niet kan worden geduld (art. 2:336 lid I BW), dan wel de belangen van hun medeaandeelhouders zodanig schaden dat het voorduren van hun aandeelhouderschap van de medeaandeelhouders niet kan worden gevergd (art. 2:343 lid I BW).

I33 Kamerstukken II 2006/07, 3I 058, nr. 3, p. I04 en Kamerstukken II 2008/o9, 3I 058, nr. 6, p. 44. 
diende te zijn dat de aandeelhouder die dit verlangde een prijs ontving gelijk aan de (werkelijke) waarde van zijn aandelen, vastgesteld door één of meer onafhankelijke deskundigen. ${ }^{134}$ De blokkeringsregeling was een instrument om de beslotenheid van de bv vorm te geven en dit wettelijke prijsbepalingsvoorschrift beoogde bescherming te bieden aan de aandeelhouder die vanwege de blokkeringsregeling niet de mogelijkheid had om met een door hem uitgekozen wederpartij de prijs van de aandelen in vrijheid uit te onderhandelen. ${ }^{\mathrm{I} 35}$

Onder het oude recht was een belangrijke vraag of het recht om de waarde van de aandelen te laten vaststellen door onafhankelijke deskundigen een 'onvervreemdbaar' recht was van de uittredende aandeelhouder. Bij het tot stand komen van de wettelijke regeling in 1928 had de toenmalige minister Donner dit onvervreemdbaarheidsprincipe met verve verdedigd in de Eerste Kamer. ${ }^{13^{6}}$ In de praktijk werd deze soep echter niet zo heet gegeten. Veelvuldig werd in aandeelhoudersovereenkomsten afgeweken van als knellend ervaren prijsbepalingsregels van de wettelijke blokkeringsregeling. Een mooi voorbeeld hiervan gaf Den Boogert tijdens het in I99I te Groningen gehouden IVO-congres. Hij noemde de contractuele afspraken die de joint venture-partners hebben gemaakt over de waardering van projecten tot exploitatie van de mogelijkheden tot gas- en oliewinning op de Noordzee bij tussentijds uittreden van een van de partners. De kans dat een rechter dergelijke contractuele regelingen terzijde zou stellen achtte hij niet groot. Het hierna te bespreken Ramsley-arrest toont aan dat Den Boogert het gelijk aan zijn zijde heeft gekregen.

Onder het nieuwe bv-recht is het mogelijk om allerlei afwijkende prijsbepalingsregels overeen te komen en in de statuten vast te leggen. Indien voldaan wordt aan de regel dat deze niet tegen de wil van de aandeelhouder worden opgelegd ${ }^{137}$ heeft de wetgever geen bezwaar tegen alternatieve prijsbepalingsmechanismen voor zover deze binnen de grenzen van de redelijkheid en billijkheid blijven. ${ }^{13^{8}}$ Voor deze prijsbepalingsregels van eigen makelij geldt niet de eis dat zij ertoe moeten strekken om de werkelijke waarde van de aandelen te bepalen. Wij zouden willen aannemen dat ten aanzien van een statutaire prijsbepalingsregel - net zoals voor een contractuele prijsbepalingsregel - niet meer geldt dan dat deze voldoende bepaalbaar moet zijn. Zowel contractuele als statutaire prijsbepalingafspraken hebben de strekking om aan de hand van tevoren overeengekomen parameters en procedures te komen tot de bepaling van de prijs voor de over te dragen aandelen. Deze contractuele en statutaire voorschriften vormen een obligatoire rechtsverhouding op grond waarvan partijen zelf, al dan niet met behulp van door hen ingeschakelde deskundigen, de prijs voor de over te dragen aandelen vaststellen. Naar onze mening staat het de aandeelhouders vrij om door hen eerder statutair overeengekomen prijsbepalingsvoorschriften bij een latere overeenkomst aan te passen. Wij zouden dus menen dat een

I34 Art. 2:I95 lid 6 BW (oud).

I35 M.J. Kroeze, 'Vragen uit de rechtsprakijk (I5). Blokkeringsregeling en prijsbepaling van aandelen', Ondernemingsrecht 2005, 69, p. 2II-2I3.

I36 Handelingen I I927/28, p. 929.

I37 Art. 2:I95 lid 4, laatste zin, BW.

I38 Kamerstukken II 2006/07, 3I 058, nr. 3, p. 52 (MvT). 
dergelijke overeenkomst in beginsel rechtsgeldig en afdwingbaar is. De norm dat sprake moet zijn van een redelijke en billijke prijsbetalingsregeling geldt onverkort. Deze norm geldt voor zowel de statutaire als de contractuele regelingen. ${ }^{139}$

Een fraai voorbeeld van een door de rechter erkende doorwerking van een contractuele prijsafspraak onder het oude recht vinden we in de zaak Ramsley B.V. c.s.|Fduw B.V. C.S. ${ }^{\text {I4O }}$ In dit arrest kwam de vraag aan de orde of bij aandeelhoudersovereenkomst kan worden afgeweken van de dwingendrechtelijke prijsbepalingsregeling die gold vóór de invoering van de Wet vereenvoudiging en flexibilisering bv-recht. Het betrof een geval waarin een drietal samenwerkende bv-aandeelhouders een aandeelhoudersovereenkomst met elkaar hadden uitonderhandeld waarin een aanbiedingsverplichting met prijsbepalingsregeling voorkwam. Een van de aandeelhouders werd vervolgens op basis van deze regeling uitgestoten. Er ontstond tussen partijen een conflict over de prijs die voor de aandelen moest worden betaald. De contractuele regeling leidde namelijk tot een lagere koopprijs dan de statutaire regeling die in overeenstemming met de wet aanknoopte bij de werkelijke waarde van de aandelen. In de procedure stelde de uitgestoten aandeelhouder dat de contractuele prijsbepaling nietig was wegens strijd met de wettelijke voorschriften. Hof 's-Gravenhage oordeelde echter anders. Het wettelijke voorschrift verbood volgens het hof uitsluitend het vaststellen van statuten die inhouden dat een aandeelhouder bij gedwongen uitkoop van zijn aandelen een prijs ontvangt die minder is dan de werkelijke waarde. De wet zweeg over overeenkomsten die een dergelijke regeling bevatten. Het hof besliste in casu dat het beginsel van de contractsvrijheid niet hoefde te wijken en liet de contractuele prijsbepalingsregeling in stand. ${ }^{\mathrm{I}}{ }^{\mathrm{I}}$

In het cassatieberoep kwam de Hoge Raad niet toe aan een oordeel over de vraag of hetgeen volgens artikel 2:I95a lid 3 BW (oud) niet in statuten kan worden opgenomen, wel rechtsgeldig in een aandeelhoudersovereenkomst kan worden bepaald. Advocaat-generaal Timmerman gaat in zijn conclusie bij dit arrest wel op deze vraag in. Timmerman sluit zich aan bij de zienswijze van het hof en acht dergelijke overeenkomsten inderdaad geldig, mits de aandeelhouders welbewust afwijken van de statuten. Sindsdien wordt ook in de lagere rechtspraak erkend dat aandeelhouders in vergaande mate hun vennootschapsrechtelijke verhouding in een overeenkomst (in plaats van in de statuten) kunnen regelen. Een voorbeeld hiervan is een uitspraak van de Rechtbank Haarlem in de zaak Jeezet. ${ }^{142}$ Het draaide in deze casus om drie aandeelhouders van een bv die een aandeelhoudersovereenkomst hadden gesloten waarin door partijen een formule was overeengekomen voor de waardering van de aandelen in geval van verplichte aanbieding door een aandeelhouder. De rechtbank

I39 Zie ook P.P. de Vries, 'Prijsbepalingsregels voor aandelen in een BV naar huidig en komend recht', Ondernemingsrecht 20I2, I9, p. I05-I08.

I40 Hof's-Gravenhage 7 augustus 2008, JOR 2008/262 en HR io juli 2009, NJ 2009, 364.

I4I Instemmend met het arrest van Hof 's-Gravenhage Chr. M. Stokkermans in zijn noot onder dit arrest, S.P. van der Waals, 'Hof 's-Gravenhage: strikt of vergaand?', JBN 2009, p. II e.v. Zie ook R.F. van den Heuvel, 'Rechtspraak vennootschapsrecht', Ondernemingsrecht 2009, p. 75 en C.A. Schwarz, 'Statutaire of contractuele prijsfixatie bij overdracht van aandelen; wijzigende gezichtspunten en de rol van redelijkheid en billijkheid', TvOB 2009, p. 20.

I42 Rb. Haarlem I5 december 20I0, JOR 20II/28I, m.nt. J.M. Blanco Fernández (Jeezet). 
nam als uitgangspunt dat het partijen vrij staat om elkaar contractueel te verbinden tot een bepaalde waardevaststelling van de aandelen, zulks in aanvulling op de dwingendrechtelijke regeling in de wet over waardebepaling door onafhankelijke deskundigen. Maar, zo voegt de rechtbank daaraan toe, er kunnen omstandigheden zijn waarin de strekking van de wettelijke en statutaire bepalingen omtrent waardering van de aandelen met zich brengt dat het naar maatstaven van redelijkheid en billijkheid onaanvaardbaar is om een aandeelhouder gebonden te achten aan een formule over waardebepaling in een aandeelhoudersovereenkomst. In casu was er gerede grond om te twijfelen aan de objectiviteit van degene die de waardebepaling had uitgevoerd en de rechtbank oordeelde daarom dat een nieuwe waardering moest worden uitgevoerd door een onafhankelijk deskundige, zij het op grond van de in de aandeelhoudersovereenkomst opgenomen formule.

Mag in de statuten van een persoonsgebonden bv ook worden verwezen naar een prijsbepalingsregeling die in de aandeelhoudersovereenkomst is vastgelegd ? Onder het oude recht was dit omstreden. In de parlementaire geschiedenis is deze vraag ook aan de orde gekomen. De minister verklaarde terzake het volgende:

'Een prijsbepalingsregeling in een aandeelhoudersovereenkomst kan daarentegen niet door een verwijzing in de statuten vennootschapsrechtelijke werking verkrijgen. Het verbod op incorporation by reference staat hier wel aan in de weg, omdat het zou neerkomen op het toekennen van vennootschapsrechtelijke werking aan een inhoudelijke regeling die niet in de statuten is opgenomen. Toekomstige aandeelhouders kunnen dus niet automatisch worden gebonden aan een contractuele prijsbepalingsregeling waarnaar in de statuten wordt verwezen. De statuten kunnen weliswaar verwijzen naar een dergelijke regeling en aan de niet-nakoming sancties verbinden maar de prijsbepalingsregeling als zodanig - en derhalve ook de statutaire sancties - binden toekomstige aandeelhouders niet. Een dergelijke regeling heeft dus slechts werking tussen bestaande aandeelhouders. ${ }^{143}$

Als wij de minister goed begrijpen, is er dus geen beletsel om in de statuten te verwijzen naar een prijsbepalingsregeling die in een overeenkomst is vastgelegd waarbij alle aandeelhouders partij zijn. De aandeelhouders hebben zich dan immers welbewust onderworpen aan de contractuele regeling waarnaar in de statuten wordt verwezen. In persoonsgebonden verhoudingen zullen toekomstige aandeelhouders doorgaans eerst moeten toetreden tot de aandeelhoudersovereenkomst alvorens zij aandelen kunnen verwerven. Het gevaar dat aandeelhouders automatisch - louter door het verwerven van aandelen - gebonden worden aan contractuele regelingen die zij niet kennen, is hier dus niet aanwezig. In persoonsgebonden verhoudingen zien wij geen bezwaar tegen een verwijzing in de statuten naar een contractuele prijsbepalingsregeling. Ook zien wij geen bezwaar indien niet-nakoming statutair wordt gesanctioneerd met opschorting van aandeelhoudersrechten. ${ }^{144}$ Dergelijke prijsbepalingsregelingen binden immers alle aandeelhouders, zijn op gelijke wijze

I43 Kamerstukken II 2008/o9, 3I 058, nr. 6, p. I-2.

I44 In dezelfde zin Dortmond 2013, nr. I72.I. 
afdwingbaar als statutaire regelingen en hebben dus ook dezelfde vennootschappelijke werking.

\subsection{Doorwerking via kwaliteitseisen voor aandeelhouders}

Een sterk instrument om te bewerkstelligen dat contractuele regelingen (mede) de vennootschappelijke verhoudingen reguleren, is het opnemen van een statutaire bepaling inhoudende dat het aandeelhouderschap uitsluitend openstaat voor personen die partij zijn bij de aandeelhoudersovereenkomst. Onder het oude recht was kwestieus of een dergelijke statutaire bepaling rechtsgeldig is. Daarover zijn er nu geen twijfels meer. In de parlementaire geschiedenis erkent de minister immers met zoveel woorden dat een dergelijke statutaire kwaliteitseis rechtsgeldig is. ${ }^{145} \mathrm{Wel}$ zal uiteraard ook hier gelden dat de inhoud van een dergelijke eis voldoende bepaalbaar moet zijn.

Onder het nieuwe bv-recht moet volgens de heersende opvatting worden aangenomen dat aan statutaire kwaliteitseisen goederenrechtelijke werking toekomt. Dit blijkt ook uit de parlementaire geschiedenis. De minister verwijst met het oog op de werking van statutaire kwaliteitseisen immers naar het bepaalde in artikel 2:195 lid 4 , tweede zin, BW. ${ }^{{ }^{4}{ }^{6}}$ Aangezien in dat lid wordt gesproken over de ongeldigheid van een aandelenoverdracht die strijdig is met de statutaire blokkeringsregeling nemen wij aan dat deze ongeldigheid evenzeer geldt voor de overdracht in strijd met een statutaire kwaliteitseis. De dogmatische verklaring van de goederenrechtelijke werking van statutaire kwaliteitseisen kan ons inziens worden gevonden in beperking van de overdraagbaarheid van aandelen die voortvloeit uit een statutaire bepaling (zijnde de kwaliteitseis) waaraan de verkrijgende aandeelhouder is onderworpen. ${ }^{\text {I } 47}$

\section{$3^{\text {B }}$ Doorwerking van stemovereenkomsten}

\subsection{Inleiding: permanente stembinding}

De principiële rechtsgeldigheid van stemovereenkomsten is in de laatste decennia algemeen aanvaard. ${ }^{\mathrm{I} 4}$ Het valt buiten het bestek van dit preadvies een overzicht te

I45 Kamerstukken II 2008/09, 3I 058, nr. 6, p. I.

I46 Kamerstukken II 2008/09, 3I 058, nr. 6, p. I.

I47 Asser/Van Solinge \& Nieuwe Weme 2-IIa` 20I3, nr. 407, p. 453-454 spreekt van een 'verkrijgingsonbevoegdheid'.

I48 Een stemovereenkomst mag niet in strijd zijn met de (vennootschappelijke) openbare orde. De vennootschappelijke openbare orde wordt door Van Schilfgaarde en Winter 2009, nr. I ook wel genoemd de 'vennootschappelijke deelrechtsorde' en door Maeijer 'de in het bijzonder door het geschreven en ongeschreven (dwingend) vennootschapsrecht bepaalde (vennootschappelijke) openbare orde' of, om in termen van Asser-Hartkamp 4-II', nr. 272 te spreken, 'in strijd met de fundamentele beginselen en algemene aanvaarde grondvesten van het rechtsstelsel betreffende NV en BV' (Asser-Maeijer 2-III^ 2000, nr. 288). Asser/Hartkamp \& Sieburgh 6-III^ 2010, nr. 345, bevat deze formulering niet meer. 
geven van deze ontwikkeling. ${ }^{149}$ Hieronder zullen wij slechts kort stilstaan bij één belangrijk onderdeel van de discussie over de principiële rechtsgeldigheid van stemovereenkomsten, namelijk de zogenoemde permanente stembinding, de afspraak om voor een onbepaald aantal gevallen of onbepaalde tijdsduur op een bepaalde wijze te stemmen. Tegenstanders van permanente stembinding betogen doorgaans dat de aandeelhouder in staat moet zijn tot een vote anticipé, waarmee wordt bedoeld dat de stembinding niet zodanig mag zijn dat de aandeelhouder in het geheel niet meer aan eigen oordeelvorming (en dus belangenafweging) kan toekomen. Aldus onder anderen Meinema in haar dissertatie, waarin ze betoogt dat er sprake is van een ongeoorloofde ontkoppeling van aandeel en stemrecht als de stemovereenkomst voor onbepaalde tijd voor alle besluiten geldt en niet opzegbaar is. Volgens de auteur dienen stemafspraken beperkt te zijn tot bepaalde categorieën van transacties of beperkt in tijd. ${ }^{150}$ Het argument dat sprake zou zijn van een ongeoorloofde loskoppeling van stemrecht lijkt ons dogmatisch onjuist, reeds op de grond dat een aandeelhouder zelf rechtsgeldig een stem kan uitbrengen. ${ }^{\mathrm{I}{ }^{\mathrm{I}}}$ Verder lijkt ons een koppeling aan tijdsduur of categorieën besluiten arbitrair.

Van Solinge \& Nieuwe Weme achten permanente stembinding principieel mogelijk:

'Wij zouden willen betogen dat de vraag of geoorloofd is een stemovereenkomst waarbij een aandeelhouder zich permanent bindt om op een bepaalde wijze of conform andermans instructies te stemmen, genuanceerd en gedifferentieerd dient te worden beoordeeld. (...) Of permanente stembinding in een bepaald geval toelaatbaar is, hangt af van alle concrete omstandigheden van dat geval, zoals de aard van de verplichting (bijv. stemonthouding of stemmen volgens instructies), de vraag of de partijen aandeelhouder of derde zijn, het doel en karakter van het geheel van afspraken tussen de betrokken partijen, de mogelijkheid van opzegging van de stemovereenkomst, de hoogte van een boetebeding en de mate waarin de desbetreffende aandeelhouder bij de vennootschap betrokken pleegt te zijn.' ${ }^{152}$

Blanco Fernández komt zonder clausulering tot principiële geoorloofdheid van permanente stembinding. Hij voegt als ondergrens toe dat in de omstandigheden van het geval de uitoefening van het stemrecht conform de eerdere stemafspraak of de afgegeven steminstructie niet onrechtmatig mag zijn. ${ }^{153}$ Vanzelfsprekend dient de uitoefening van het stemrecht op grond van de (permanente) stembinding niet in strijd met de redelijkheid en billijkheid van artikel 2:8 BW te zijn. ${ }^{154}$

I49 Asser/Maeijer/Van Solinge \& Nieuwe Weme 2-II^ 2009, nrs. 38I-388 met uitgebreide literatuur.

I50 Meinema 2003, p. I97 (zie ook p. I93). In soortgelijke zin Van Schilfgaarde/Winter 2009, nr. 67 en Dortmond 2013, nr. 2I7.I.

I5I Dat de rechter onder omstandigheden een vorm van doorwerking kan aannemen doet aan de onjuistheid van dit argument niet af.

I52 Asser/Maeijer/Van Solinge \& Nieuwe Weme 2-II* 2009, nr. 385.

I53 Blanco Fernández, WPNR 2005, p. 5 I6.

I54 De vrijheid om het eigen belang te dienen wordt begrensd door het vangnet dat de belangen van andere betrokkenen, zoals dat van de vennootschap en die van de overige aandeelhouders, niet onevenredig mogen worden geschaad (vgl. art. 3:13 lid 2 BW). Ook kunnen zich na het sluiten van de stemovereenkomst omstandigheden openbaren waardoor het naleven van contractuele 
Wij merken op dat de Asser spreekt van stemmen op een bepaalde wijze of conform de instructie van een andere aandeelhouder. Dat zijn twee verschillende dingen. In persoonsgebonden vennootschappen zal de ene aandeelhouder zich niet snel verplichten om in de toekomst 'blind' conform de instructies van de andere te stemmen, maar de aandeelhouders zullen zich doorgaans wel op vele gebieden voor onbepaalde duur hebben verbonden om op een in de stemovereenkomst vastgelegde wijze te stemmen. De vraag rijst dan of in het kader van de discussie over de geoorloofdheid van permanente stembinding een principieel verschil tussen deze twee situaties bestaat. ${ }^{155}$ Dortmond lijkt, als wij hem goed begrijpen, permanente stembinding mogelijk te achten in joint venture-verhoudingen waarbij de aandeelhouders zich hebben verbonden om op een in de aandeelhoudersovereenkomst vastgelegde wijze te stemmen. Niet toegestaan is volgens hem een permanente stembinding waarbij de ene aandeelhouder zich verplicht om voortdurend volgens de aanwijzing van de ander te stemmen. ${ }^{156} \mathrm{Wij}$ menen dat er geen principieel verschil tussen deze twee situaties bestaat. Wel zal permanente stembinding doorgaans sneller als geoorloofd worden beschouwd in de situatie waarbij alle aandeelhouders zich tevoren hebben verbonden om op een in de stemovereenkomst aangegeven wijze te stemmen.

\subsection{Doorwerkingsjurisprudentie met betrekking tot stemovereenkomsten}

In de rechtspraak en literatuur van de afgelopen vijftien jaar is het principe van vennootschappelijke werking van stemovereenkomsten allengs erkend. In I999 betrok Blanco Fernández de stelling dat als bij persoonsgebonden vennootschappen (hij spreekt van 'een zekere identiteit' tussen de aandeelhouders en de algemene vergadering), ${ }^{157}$ een stem wordt uitgebracht in strijd met de stemovereenkomst, het desbetreffende besluit vernietigbaar is wegens strijd met de redelijkheid

stemverplichtingen zou leiden tot handelen in strijd met vennootschapsrechtelijke verplichtingen van de aandeelhouder. Het kan dan naar maatstaven van redelijkheid en billijkheid onaanvaardbaar zijn om de aandeelhouder aan zijn contractuele stemverplichting te houden (Asser/Maeijer/Van Solinge \& Nieuwe Weme 2-II^ 2009, nr. 387). In deze situaties zal er, afhankelijk van de concrete omstandigheden van het geval, geen sprake kunnen zijn van doorwerking van de stemovereenkomst.

I55 Blanco Fernández, WPNR 2005, p. 515-516, bespreekt de permanente stembinding in de 'blinde' variant waarbij de aandeelhouder(s) zich verplicht(en) conform de instructies van een ander (aandeelhouder of derde) te stemmen.

I56 Dortmond 2013, nr. 217.I. In zijn oratie stelde Dortmond nog dat permanente stembinding alleen mogelijk is bij vennootschappen waarvoor een (verplichte) registratiedatum geldt, dat wil zeggen beursvennootschappen (P.J. Dortmond, Stemovereenkomsten rondom de eeuwwisseling (oratie Leiden), Deventer: Kluwer 2000, p. 17). Voor kritiek op deze stelling zie onder meer Asser/Maeijer/Van Solinge \& Nieuwe Weme 2-II^ 2009, nr. 385, en Van Schilfgaarde/Winter 2009, nr. 67. In Dortmond 2013 is de auteur kennelijk tot een ander inzicht gekomen, want daarin komt die stelling niet meer voor.

I57 J.M. Blanco Fernández, 'Vennootschapsrechtelijke werking van stemovereenkomsten', Ondernemingsrecht 1999, p. I50, gaat ook in op de mogelijkheid dat niet alle aandeelhouders partij zijn bij de stemovereenkomst, in welk geval volgens hem geen sprake is van doorwerking. Hij neemt wel doorwerking aan als niet alle aandeelhouders partij zijn maar de niet partij zijnde aandeelhouders het vertrouwen van aanvaarding van de stemovereenkomst hebben gewekt. Wij gaan hier verder niet op in. 
en billijkheid. Die identiteit is volgens de auteur in ieder geval aanwezig als alle aandeelhouders partij zijn bij de stemovereenkomst. ${ }^{158}$ Van Solinge \& Nieuwe Weme betogen dat er, als alle aandeelhouders partij bij de stemovereenkomst zijn, sprake kan zijn van een dergelijke vennootschappelijke doorwerking 'afhankelijk van de concrete omstandigheden'. ${ }^{159}$ Indien naast de aandeelhouders ook de vennootschap partij is bij de overeenkomst, zouden Van Solinge \& Nieuwe Weme vennootschapsrechtelijke doorwerking als regel willen aannemen. ${ }^{160}$

Vastgesteld kan worden dat het aannemen van vennootschappelijke werking van stemovereenkomsten inmiddels heersende opvatting is. In de volgende paragrafen gaan wij in op de vraag wat die werking inhoudt, of de vennootschap partij of anderszins betrokken bij de stemovereenkomst dient te zijn en op de mogelijke vennootschappelijke rechtsgevolgen van een in strijd met een stemafspraak uitgebrachte stem, maar eerst laten wij de belangrijkste uitspraken over doorwerking van stemovereenkomsten de revue passeren.

Een van de eerste uitspraken ${ }^{16 \mathrm{I}}$ waarin een vorm van doorwerking werd erkend, was de Chipshol-zaak (I996). ${ }^{162}$ In die zaak was tussen de aandeelhouders afgesproken dat een bepaalde persoon niet tot gedelegeerd commissaris zou worden benoemd. Door de stemovermacht van de ene aandeelhouder geschiedde dit toch. Het hof rekende het aan de vennootschap toe dat haar bestuur niet bereid was een algemene vergadering bijeen te roepen waarin de benoeming kon worden teruggedraaid; daardoor handelde de vennootschap onrechtmatig jegens de benadeelde aandeelhouder. De Hoge Raad liet dat oordeel in stand.

De eerste echte doorwerkingsuitspraak werd in 1998 in een kortgedingzaak gewezen. $^{16_{3}}$ In die zaak (VenV) eisten de statuten van de joint venture-vennootschap voor bepaalde categorieën bestuursbesluiten een goedkeuring van de algemene vergadering met een meerderheid die lager was dan de meerderheid die partijen in de stemovereenkomst waren overeengekomen. De president van de rechtbank ging - tamelijk revolutionair - ervan uit dat de partijen (tijdelijk) van een statutaire meerderheidseis beoogden af te wijken en oordeelde dat zulks geoorloofd was. Het beroep op de contractuele meerderheidseis werd door de rechtbank rechtens

I58 Blanco Fernández, Ondernemingsrecht 1999, p. I48-I5I. Instemmend: G.J.H. van der Sangen, 'Aandeelhoudersovereenkomsten in besloten verhoudingen', Stichting, Vereniging \& Vennootschap 2003, p. 40 en Meinema 2003, p. 208. Zie verder o.a. Van Schilfgaarde, WPNR 2002, p. 640, die schreef dat 'erkenning van een zekere vennootschappelijke werking onontkoombaar' is. Anders: Ten Berg, preadvies 2002, p. I86, die vindt dat Blanco Fernández 'wel erg ver - of te ver' gaat in het 'opzij zetten van de geldende institutionele leer'.

I59 Asser/Maeijer/Van Solinge \& Nieuwe Weme 2-II^ 2009, nr. 387 . Eveneens in deze zin: Van Schilfgaarde/Winter 2006, nr. 67, en, terughoudend: Ten Berg, preadvies 2002, p. I85-I86.

I6o Vgl. Van Schilfgaarde, WPNR 2002/6503, p. 640, die eveneens ervan uitgaat dat de vennootschap partij bij de overeenkomst is.

I6I Als voorloper van de doorwerkingsjurisprudentie wordt wel beschouwd de Sluis-uitspraak, OK 24 januari I99I, NJ I99I, 224 (Sluis), waarin sprake was van wanbeleid op de grond dat een van de aandeelhouders niet wilde meewerken aan een overeengekomen statutenwijziging.

I62 HR 29 november I996, JOR I997/28 (Chipshol).

I63 Rb. Middelburg (pres.) I4 april I998, JOR 2000/25 (VenV). 
aanvaard, maar in casu afgewezen op de grond dat het beroep erop naar maatstaven van redelijkheid en billijkheid onaanvaardbaar was.

In de Versatel-uitspraak (1999) overwoog de OK dat de voor een aandeelhouder uit een joint venture-overeenkomst voortvloeiende afspraken hem niet zonder meer ontnomen kunnen worden enkel op de grond dat besluitvorming naar de regels van vennootschapsrecht in strikte zin op correcte wijze heeft plaatsgevonden. ${ }^{\text {.64 }}$ In de Skygate-zaak (200I) kwam de OK tot het oordeel wanbeleid onder meer op basis van een emissiebesluit dat in strijd was met de aandeelhoudersovereenkomst (en bovenal) ongeschikt was om de financiële nood te lenigen. ${ }^{165}$ Ook uit de Broadnetuitspraak (2002) van de OK blijkt dat de vennootschap haar handelen (in casu het verschaffen van informatie) mede moet laten bepalen door een tussen de aandeelhouders gesloten aandeelhoudersovereenkomst. ${ }^{166}$ Het oordeel van de OK komt erop neer dat de aandeelhoudersovereenkomst de wijze van besluitvorming binnen de vennootschap mede bepaalt. ${ }^{167}$ Uit deze enquêtezaken kan voorts worden afgeleid dat schending van een aandeelhoudersovereenkomst wanbeleid kan opleveren.

Het voorlopige sluitstuk in de doorwerkingsjurisprudentie wordt gevormd door de uitspraak in de zaak Vanka-Kawat van de Rechtbank Den Haag uit augustus 2012. ${ }^{\text {168 }}$ In deze zaak ging het om de afspraak tussen twee aandeelhouders dat, zolang een van beiden nog bestuurder zou zijn, de statutaire winstverdelingsregeling niet ten nadele van hem zou worden gewijzigd. In strijd met de afspraak werden de statuten gewijzigd en gaf de raad van commissarissen $(\mathrm{RvC})$ nieuwe aandelen aan een derde uit. De rechtbank oordeelde, voor zover ons bekend voor de eerste keer, met zoveel woorden dat van 'vennootschapsrechtelijke werking van de aandeelhoudersovereenkomst' moet worden uitgegaan in een geval waarin de twee aandeelhouders en de vennootschap partij bij de aandeelhoudersovereenkomst waren. De rechtbank oordeelde dat het besluit in kwestie vernietigbaar is wegens strijd met artikel 2:8 BW. Wij achten dit oordeel juist. ${ }^{169}$

\section{Io De vennootschap als partij bij de stemovereenkomst}

De meningen lopen uiteen over de vraag of het voor doorwerking van een stemovereenkomst in de vennootschappelijke rechtssfeer noodzakelijk is dat de vennootschap daarbij partij is. Uit bijna alle hierboven besproken uitspraken blijkt niet duidelijk of dat het geval was; de rechter legde er in ieder geval geen nadruk

I64 OK 20 mei I999, JOR 2000/72 (Versatel). De uitspraak is niet erg helder geformuleerd en te weinig dogmatisch onderbouwd om er verdergaande conclusies uit te trekken; annotator Blanco Fernández komt tot diezelfde constatering. Hetzelfde geldt voor OK 28 december 2005, JOR 2006/66 (Wielens/Gekas), waarin de OK uit de opstelling van een van de joint venture-partijen afleidt dat deze een koers voorstaat die afwijkt 'van de hiervoor voor mogelijk gehouden uitgangspunten' van de joint venture en reeds daarom een onderzoek beveelt.

I65 OK I8 januari 200I, JOR 200I/35 (Skygate).

I66 OK 8 mei 2002, JOR 2002/II2 (Broadnet). De uitspraken Hof Amsterdam 25 april 2002, JOR 2002/I28 (GorillaPark) en OK I5 november 200I, JOR 2002/6 (Decidewise) worden hier niet besproken omdat zij onzes inziens niet direct relevant zijn voor het leerstuk van de doorwerking.

I67 Aldus ook annotator Blanco Fernández.

I68 Rb. Den Haag I augustus 20I2, JOR 20I2/286 (Vanka-Kawat).

I69 Zie over deze uitspraak verder paragraaf 3.I2. 
op. Dat was anders in de zaak Vanka-Kawat. Daar ging de rechtbank nadrukkelijk uit van vennootschappelijke werking op de grond dat beide aandeelhouders én de vennootschap zich aan de aandeelhoudersovereenkomst hebben gebonden. ${ }^{170}$ Van Schilfgaarde en Van Solinge \& Nieuwe Weme gaan zoals gezegd als regel uit van doorwerking als de vennootschap partij bij de overeenkomst is. ${ }^{171}$ Dortmond gaat van (beperkte) vennootschappelijke werking uit als alle aandeelhouders partij zijn bij de overeenkomst en de vennootschap 'zich akkoord heeft verklaard' met die overeenkomst, dan wel dat de statuten eisen dat de aandeelhouders partij bij de overeenkomst zijn. ${ }^{172}$ Blanco Fernández stelt zich op het standpunt dat als regel van doorwerking kan worden uitgegaan als alle aandeelhouders partij zijn bij de overeenkomst; er is dan sprake van identiteit van partijen en aandeelhouders (algemene vergadering). ${ }^{173} \mathrm{Wij}$ zijn het met dit laatste standpunt eens. Onzes inziens is het partij zijn of zich akkoord verklaren door de vennootschap geen vereiste voor het tot stand komen van vennootschappelijke werking. Wel zal het doorgaans een praktische noodzaak zijn dat de vennootschapsleiding kennis heeft genomen van de stemovereenkomst. ${ }^{174}$

\section{II Binding bestuurders en commissarissen aan stemovereenkomst van aandeelhouders}

Een bijzondere vorm van 'doorwerking' doet zich voor bij de vraag of ook bestuurders en commissarissen gebonden kunnen zijn aan een stemovereenkomst tussen de aandeelhouders (of aan een aandeelhoudersovereenkomst in het algemeen). ${ }^{175}$ Deze vraag deed zich voor in de hierboven reeds besproken uitspraak van de Rechtbank Den Haag. Bijzonderheid in die zaak was dat de (enige) commissaris tevens een van de aandeelhouders was. Deze had - kort samengevat - in strijd met de aandeelhoudersovereenkomst een ( $\mathrm{RvC}$-)besluit genomen tot uitkering van een bonus aan een bestuurder. De rechtbank oordeelt dat gebondenheid van een commissaris aan een aandeelhoudersovereenkomst in de regel niet aanvaardbaar is gelet op het feit dat een commissaris het vennootschappelijk belang heeft te dienen. Dat oordeel is conform de heersende opvatting. ${ }^{176}$ De rechtbank vervolgt dat in een geval als het onderhavige (daarmee kennelijk doelend op het feit dat de aandeelhouder

I70 Mogelijk speelde daarbij de procesrechtelijke positie van de vennootschap als verweerder een rol.

I7I Van Schilfgaarde/Winter 2009, nr. I; Asser/Maeijer/Van Solinge \& Nieuwe Weme 2-II^ 2009, nr. 385 .

172 Dortmond 2013, nr. 217.2.

I73 Ondernemingsrecht I999, p. I50 en Van der Sangen, SV\&V 2003, p. 40.

I74 Naar het recht van Curaçao is binding van de vennootschap aan de "vennootschappelijke overeenkomst' een voorwaarde voor de vennootschappelijke werking ervan (zie paragraaf I).

I75 Dit is een iets andere vraag dan de vraag of de vennootschap partij bij de overeenkomst moet zijn om vennootschappelijke werking ervan aan te nemen; die vraag wordt in de volgende paragraaf besproken. Dit is eveneens een andere vraag dan die of bestuurders en commissarissen zich in een onderlinge (stem)overeenkomst kunnen verbinden; die vraag komt in dit preadvies niet aan de orde.

I76 Vgl. Asser/Maeijer/Van Solinge \& Nieuwe Weme 2-II* 2009, nr. 423 met betrekking tot stemovereenkomsten van bestuurders met een derde of met andere bestuurders. 
tevens commissaris was) verlangd mocht worden dat de commissaris zich 'in overeenstemming met de aandeelhoudersovereenkomst zou gedragen, zolang niet evident sprake zou zijn van strijd met het vennootschappelijk belang.' Ook dit oordeel achten wij juist. Wij zouden verder willen aannemen dat een commissaris, ook als hij niet tevens aandeelhouder is, bij de vervulling van zijn taak rekening zal moeten houden met de inhoud van een aandeelhoudersovereenkomst, tenzij de uitvoering ervan in strijd is met het vennootschappelijk belang. Zoals gezegd wordt dat in persoonsgebonden vennootschappen grotendeels door het aandeelhoudersbelang ingekleurd). ${ }^{177}$

\subsection{Rechtsgevolg van een in strijd met een stemovereenkomst genomen besluit}

Zoals gezegd oordeelde de Rechtbank Den Haag dat de tussen partijen geldende aandeelhoudersovereenkomst vennootschappelijke werking heeft en dat een in strijd met een stemovereenkomst genomen besluit 'dientengevolge' vernietigbaar is op grond van de redelijkheid en billijkheid die in acht moeten worden genomen door hen die bij de organisatie van de rechtspersoon zijn betrokken (artikel 2:8 BW). ${ }^{178}$ Aantastbaarheid van een besluit dat is genomen doordat een (of meer) van de aandeelhouders in strijd met de stemafspraak heeft gestemd, is onzes inziens een logisch uitvloeisel van de doorwerkingsjurisprudentie. ${ }^{179}$

Intussen is dit rechtsgevolg niet het enig denkbare. De in de literatuur geopperde alternatieven zijn: de niet conform de stemafspraak uitgebrachte stem is nietig; ${ }^{180}$ het besluit is vernietigbaar op grond van een analogische toepassing van artikel 2:15 lid I, onder c, BW (strijd met een reglement) ${ }^{\mathrm{I} 8 \mathrm{I}}$ het besluit is nietig. ${ }^{\mathrm{I} 22}$ Verdedigbaar is voorts dat het besluit geldig is maar het houden van de medeaandeelhouders aan het stemresultaat naar maatstaven van redelijkheid en billijkheid onaanvaardbaar is

I77 Naar het recht van Curaçao is binding van bestuurders en commissarissen aan de 'vennootschappelijke overeenkomst' een voorwaarde voor de vennootschappelijke werking ervan (zie paragraaf I).

I78 Aldus reeds Blanco Fernández, Ondernemingsrecht 1999, p. I50.

I79 Blanco Fernández, Ondernemingsrecht 1999, p. I50. In gelijke zin: Van der Sangen, SV\&V 2003, p. 40. Anders: Dortmond 2013, nr. 217.2, die vindt dat de uitspraak 'te ver' gaat.

I80 Vgl. Blanco Fernández, Ondernemingsrecht I999, p. I50, Van der Sangen, SV\&V 2003, p. 40. Als men deze variant zou willen bepleiten zou men kunnen wijzen op de parallel van stemuitbrenging door een gevolmachtigde in strijd met een in de stemvolmacht vervatte steminstructie. Asser/Maeijer/Van Solinge \& Nieuwe Weme 2-II^ 2009, nr. 356, acht de stem in dat geval nietig op grond van overschrijding van de vertegenwoordigingsbevoegdheid (wij voelen meer voor het standpunt van Van der Grinten dat de steminstructie een norm is die slechts geldt in de relatie tussen volmachtgever en gevolmachtigde). Het gaat daarbij, voor alle duidelijkheid, om een instructie in een volmacht van de aandeelhouder, terwijl het in het onderhavige geval gaat om een instructie aan de aandeelhouder, maar het punt van vergelijking is de nietigheid van de stem.

I8I Vgl. Blanco Fernández, Ondernemingsrecht I999, p. I50, die stelt dat deze analoge toepassing voor de hand ligt. Deze vernietigingsgrond heeft als voordeel boven de vernietigingsgrond van strijd met de redelijkheid en billijkheid dat er minder ruimte is voor rechterlijke toetsing of in het concrete geval sprake is van strijd met de redelijkheid en billijkheid.

I82 Blanco Fernández, Ondernemingsrecht I999, p. I50, die dit rechtsgevolg als alternatief voor vernietigbaarheid voorstelt. In zijn noot onder de Vanka-Kawat-uitspraak betuigt Blanco Fernández instemming met de door de rechtbank aangenomen vernietigbaarheid van het besluit op grond van strijd met art. 2:8 BW. 
(artikel 2:8 lid 2 BW). Aan al deze rechtsgevolgen kleeft echter één nadeel: als er ten gevolge van de in strijd met de stemafspraak uitgebrachte stem geen besluit wordt genomen (bijvoorbeeld als de meerderheidsaandeelhouder in strijd met de stemafspraak tegen een voorgenomen besluit stemt), heeft aantastbaarheid van het besluit geen zin. In deze situatie zou een ander rechtsgevolg efficiënter zijn, bijvoorbeeld dat de stem wordt geacht conform de stemovereenkomst te zijn uitgebracht. Maar het is de vraag of doorwerking in de vorm van zo'n vergaand rechtsgevolg op de redelijkheid en de billijkheid kan worden gebaseerd. ${ }^{183}$ In een dergelijk geval ligt het meer voor de hand een nieuwe vergadering bijeen te roepen en de rechter een gebod tot stemuitbrenging conform de stemovereenkomst te vragen. ${ }^{184}$

In de situatie waarin de meerderheidsaandeelhouder in strijd met de stemafspraak zijn stem uitbrengt, en aldus het aannemen van het besluit bewerkstelligt, is dus doorwerking in de vorm van vernietigbaarheid beschikbaar. Maar wat als er meerdere aandeelhouders zijn, van wie er een aantal in strijd met de stemafspraak vóór stemt, waardoor het besluit wordt aangenomen? Kan deze situatie ook tot vernietiging van het besluit leiden? Dat hangt onzes inziens af van alle omstandigheden van het geval. ${ }^{185}$

Een heel andere situatie is aan de orde als de stemmen zijn uitgebracht conform een nietige of vernietigde stemovereenkomst. Formeel gezien is de stemuitbrenging geldig als zij geschiedt door een stemgerechtigde aandeelhouder. Afhankelijk van de omstandigheden is redressering op grond van een wilsgebrek denkbaar. ${ }^{186}$

De vraag rijst of opname van de stemovereenkomst in de statuten tot een ander rechtsgevolg leidt wanneer er in strijd met de stemafspraak wordt gestemd. Strikt genomen is er dan sprake van een besluit genomen in strijd met de statuten; het besluit zou dan nietig zijn op grond van artikel 2:I4 BW. In het verlengde hiervan rijst de vraag of in de statuten kan worden bepaald dat een niet conform een stemafspraak uitgebrachte stem ongeldig ${ }^{187}$ is of geacht moet worden conform de stemafspraak te zijn uitgebracht. Het eerste achten wij verdedigbaar; bij het tweede aarzelen wij zoals eerder gezegd. Verder zou men wellicht kunnen denken aan een statutaire bepaling dat besluiten alleen rechtsgeldig kunnen worden genomen als de stemmen conform de stemafspraak zijn uitgebracht.

I83 Bovendien zou men kunnen zeggen dat in deze opvatting de niet conform de afspraak stemmende aandeelhouder het recht op wanprestatie wordt ontnomen.

I84 Hetzelfde kan men uiteraard doen als een besluit in strijd met de stemovereenkomst is genomen (en doorwerking niet aan de orde is).

I85 Als alle aandeelhouders in strijd met de stemovereenkomst stemmen, kan onder omstandigheden sprake zijn van een stilzwijgende amendering van de stemovereenkomst.

I86 Zie art. 3:44 BW (bedreiging, bedrog en misbruik van omstandigheden) en art. 6:228 BW (dwaling).

I87 T.P. van Duuren, 'Stem- en samenwerkingsafspraken bij de persoonsgebonden BV', in: P.J. van der Korst e.a. (red.), Handboek Onderneming en aandeelhouder (serie OOR, deel 69), Deventer: Kluwer 20I2, p. I48, construeert hetzelfde rechtsgevolg via statutaire opschorting van stemrecht. 


\subsection{Het verschil in rechtsgeldigheid van de diverse vormen van afspraken tussen aandeelhouders}

De grondslag van de doorwerking van stemovereenkomsten in het vennootschapsrecht bestaat onzes inziens uit de volgende drie componenten:

I. partijautonomie en contractsvrijheid, dat wil zeggen de vrijheid van partijen om zich te binden ten aanzien van de wijze waarop zij als aandeelhouder hun stem uitbrengen;

2. contractspartijen en algemene vergadering bestaan uit dezelfde personen ('identiteit'), dat wil zeggen dat alle partijen bij de overeenkomst tevens aandeelhouder in de vennootschap zijn en derhalve de algemene vergadering van die vennootschap vormen;

3. de redelijkheid en billijkheid die alle bij de vennootschap betrokkenen jegens elkaar in acht dienen te nemen (artikel 2:8 BW).

De onderliggende vraag in het doorwerkingsleerstuk is of het in de heersende opvatting aangenomen verschil in rechtsgeldigheid en rechtsgevolg van afspraken vastgelegd in de statuten, het reglement, het besluit dan wel de overeenkomst, in persoonsgebonden vennootschappen nog wel ten volle geldt c.q. dient te gelden. Hieronder wordt die vraag aan de hand van twee voorbeelden besproken.

Zoals in paragraaf 2 aangegeven kunnen regelingen inzake de wettelijke bevoegdheidsverdeling en de duurzame structuur die op grond van de openbaarheidsfunctie van dwingend recht in de statuten moeten worden neergelegd, niet in een buitenstatutaire regeling worden neergelegd. Zoals gezegd nemen wij aan dat deze categorie klein is. Per geval zal dus moeten worden onderzocht of hiervan sprake is, waarbij ook de betekenis van tournures als 'de statuten kunnen bepalen' dient te worden meegewogen. Soms geeft de wet aan dat een regeling zoals hier bedoeld ook 'krachtens' de statuten kan worden gegeven. Daaronder wordt in de heersende opvatting alleen verstaan: in een reglement of besluit. Als voorbeeld noemen wij de mogelijkheid om bestuursbesluiten op grond van artikel 2:239 lid 3 BW bij of krachtens de statuten aan de goedkeuring van (bijvoorbeeld) de algemene vergadering te onderwerpen. Wij zouden willen aannemen dat een contractuele bepaling van die strekking geldig is. De openbaarheidsfunctie is uitgewerkt door de vermelding in de statuten dat er een buitenstatutaire goedkeuringsregeling is. Het behoort dan onzes inziens voor de rechtsgeldigheid ervan geen verschil te maken of de regeling in een reglement of een overeenkomst is neergelegd. ${ }^{188} \mathrm{Wij}$ zouden verder willen aannemen dat een bestuurder die van een contractuele goedkeuringsregeling op de hoogte is maar haar niet in acht neemt, zijn taak onbehoorlijk vervult en dat het zonder de vereiste goedkeuring genomen bestuursbesluit niet mag worden uitgevoerd totdat de goedkeuring alsnog is verkregen. Ten slotte zouden wij willen aannemen dat het bestuursbesluit vernietigbaar is wegens strijd met de redelijkheid en

I88 Vgl. Van Schilfgaarde, WPNR 2002, p. 28. 
billijkheid die het bestuur jegens de aandeelhouders in acht dient te nemen. ${ }^{\mathrm{I} 89} \mathrm{Wij}$ zien in dit opzicht wat het rechtsgevolg betreft geen verschil met een goedkeuringseis die krachtens de statuten in een reglement is opgenomen.

Een soortgelijke situatie als hierboven geschetst doet zich voor als besluitvormingsregels, zoals quorum- of meerderheidseisen, in een overeenkomst zijn opgenomen. ${ }^{\text {I9o }}$ Dergelijke besluitvormingsafspraken komen in de praktijk vaak voor; hun rechtsgeldigheid wordt, zoals gezegd, algemeen aanvaard. In dat verband rijst de vraag wat rechtens is als een (latere) buitenstatutaire regeling (bewust) afwijkt van een statutaire regeling. In het hierboven reeds besproken geval dat werd voorgelegd aan de President van de Rechtbank Middelburg, bepaalden de statuten dat bestuursbesluiten aan de goedkeuring van de algemene vergadering waren onderworpen, welke goedkeuring diende te worden gegeven bij besluit genomen met twee derde van de uitgebrachte stemmen. ${ }^{\text {III }}$ In de aandeelhoudersovereenkomst werd hiervoor echter unanimiteit geëist. De President oordeelde dat op grond van de redelijkheid en de joint venture-verhoudingen beide regelingen dienden te worden nageleefd. Dit oordeel is naar onze mening juist. De President kwam niet toe aan de vraag of het besluit geldig zou zijn geweest als het conform de statuten met twee derde van de stemmen zou zijn genomen. Wij zouden menen, in de lijn van het hierboven inzake een contractuele goedkeuringseis betoogde, dat het besluit in dat geval vernietigbaar is op grond van de redelijkheid en billijkheid die de aandeelhouders jegens elkaar in acht dienen te nemen.

Een interessante vraag is wat rechtens is als partijen in een latere overeenkomst bewust een lagere meerderheid afspreken dan in de statuten is voorgeschreven. Een besluit genomen met de contractueel vereiste meerderheid zou dan in strijd met de statuten zijn en conform artikel 2:I4 BW nietig. Wij zouden menen dat het conform een contractuele afspraak genomen besluit tussen de aandeelhouders in hun onderlinge verhouding als rechtsgeldig dient te gelden. Men zou ook kunnen zeggen dat de beperkende werking van de redelijkheid en billijkheid in zo'n geval met zich brengt dat een aandeelhouder zich niet op (strijd met) de statutaire bepaling kan beroepen. ${ }^{192}$ Zo brengt onzes inziens een uitkerings- of dechargebesluit genomen met een contractuele meerderheid die lager is dan de statutair voorgeschreven meerderheid, jegens de aandeelhouders (c.q. de bestuurders) het door de aandeelhouders

I89 Art. 2:I5 lid I, onder b, BW of op grond van analoge toepassing van strijd met een reglement (art. 2:I5 lid I, onder c, BW).

I9o De heersende opvatting met betrekking tot besluitvorming door het bestuur is dat deze regels behalve in de statuten ook in een reglement kunnen staan. Afwijking van 'de normale besluitvormingsregels' vereist wel een statutaire verankering: zie Asser/Maeijer/Van Solinge \& Nieuwe Weme 2-II^ 2009, nr. 420.

I9I Rb. Middelburg (pres.) I4 april I998, JOR 2000/25 (VenV).

I92 L. Timmerman, Nieuwe algemene bepalingen van Boek 2 BW (Preadvies en verslag I99I Vereeniging 'Handelsrecht'), Zwolle: W.E.J. Tjeenk Willink I992, p. 65, betoogt dat als art. 2:8 lid 2 BW een beroep op de statutaire bepaling niet toestaat, een besluit in strijd met de statuten toch rechtsgeldig kan zijn. Als men dit betoog niet wil volgen, zou men ook kunnen aansluiten bij hetgeen in paragraaf 2 is gezegd ten aanzien van unanieme aandeelhoudersbesluiten in strijd met de statuten. 
beoogde rechtsgevolg tot stand. Dit betekent dat de aandeelhouders c.q. de vennootschap dit besluit tegen zich moeten laten gelden, ook al is niet aan een (eerder) in de statuten vastgelegde zwaardere meerderheidseis voldaan. In paragraaf $3 \mathrm{~A}$ hebben wij geconcludeerd dat statutaire verplichtingen van aandeelhouders onderling bij latere overeenkomst kunnen worden gewijzigd. Wij zien geen reden om in het onderhavige geval tot een andere conclusie te komen.

In het verlengde hiervan kan een meer algemene constatering worden gedaan. De aandeelhouders in persoonsgebonden vennootschappen werken met verschillende soorten documenten waarin ze hun samenwerking tot stand brengen, aanvullen, wijzigen en beëindigen: overeenkomst, statuten, reglementen en besluiten. De in de doctrine ontwikkelde vennootschappelijke 'hiërarchie' tussen deze documenten is doorgaans niet bepalend voor de keuze van de aandeelhouders in welk van de genoemde documenten ze welke afspraken maken. Het gaat bij alle documenten in de eerste plaats gaat om de wilsovereenstemming van de gezamenlijke aandeelhouders in het kader van hun samenwerking. Op een handvol gevallen na zou het naar onze mening de partijen moeten vrijstaan om zonder verschillen in rechtsgeldigheid en rechtsgevolgen te bepalen in welk document ze hun afspraken vastleggen.

Een woord tot slot. Het doorwerkingsleerstuk heeft de afgelopen jaren een sterke ontwikkeling doorgemaakt en contractuele vormgeving van de vennootschappelijke verhoudingen van aandeelhouders is inmiddels gemeengoed geworden. Deze tendens tot contractualisering van het vennootschapsrecht heeft door de invoering van de Wet vereenvoudiging en flexibilisering bv-recht op I oktober 2012 stevige rugdekking gekregen. Wij verwachten niet dat het einde van deze ontwikkeling al in zicht is. 